\title{
The Role of Party Politics in Medical Malpractice Tort Reforms
}

\author{
Ulrich Matter ${ }^{a}$ \\ Alois Stutzer $^{b}$ \\ (University of Basel) \\ (University of Basel)
}

December 3, 2015

\begin{abstract}
The U.S. tort system has experienced various reforms over the last three decades. While there is an extensive literature on the consequences of these reforms, very little is known about their determinants. In this study, we investigate the role of party politics in the reform process across U.S. states. In order to test whether any party effect goes beyond voter preferences, we apply the idea behind regression discontinuity studies based on close electoral outcomes to semi-parametric proportional hazards models. We find that in states with close election outcomes, a narrow Republican majority in the lower house is associated with a 50 to 150 percent higher risk of tort reform enactment compared to a narrow Democratic majority. Our results indicate that party politics plays a role in tort reforms goes over and above potential underlying preferences in the constituency. (JEL classification: D72, K13)
\end{abstract}

Keywords: Tort reform, medical malpractice, partisan effect, legislatures, survival analysis, RDD

\footnotetext{
${ }^{a}$ University of Basel, Faculty of Business and Economics, Peter-Merian-Weg 6, 4002 Basel, Switzerland, phone: +41-(0)61 26733 03, ulrich.matter@unibas.ch

${ }^{b}$ Corresponding author; University of Basel, Faculty of Business and Economics, Peter-Merian-Weg 6, 4002 Basel, Switzerland, phone: +41-(0)61 26733 61, alois.stutzer@unibas.ch
} 


\section{Introduction}

Since the 1980s the reform of tort law ${ }^{1}$ has become an increasingly important political issue in the United States. Many state legislatures have passed statutes to reshape their mainly common-law-based law of torts. While the nature and extent of these reform efforts vary significantly across U.S. states, the reforms generally point in the same direction and aim at a reduction in the number of tort suits as well as the amount of damages awarded. The reform process as well as the expansion of tort liability and damages preceding it in the 1960s and 1970s are difficult to understand as an evolutionary process towards an efficient system. They reflect, rather, a complicated interaction of interest representation in the compensation of injured parties that has become big business ${ }^{2}$

In this paper, we study the role of party politics in legislative tort reforms in U.S. states. It has been argued that tort reforms became a highly partisan topic, with Republicans taking sides with the business community and being in favor of reforms and Democrats being pro plaintiff and against reforms Sugarman 2002), although these positions are historically and ideologically unclear (Sugarman 2006). The two parties channel many different politico-economic forces. The Democrats' opposition to tort reforms goes along with generous campaign contributions from trial lawyers (Zywicki 2000). It has also long been argued that special interest groups shape U.S. tort law in their pursuit of economic rents (e.g., Epstein 1988, Rubin and Bailey 1994, Rubin 2005, Zywicki 2000). The legal changes that expanded tort liability were mainly brought about by litigation and judicial action favored and supported by organized groups of attorneys (see Rubin et al. 2001 for theoretical arguments as well as observational evidence) ${ }^{3}$ In response, defense interests began to form around groups of businesses and medical doctors 4 For them, the legislative process was relatively more accessible than the judicial process, and tort reform became an important issue in the political arena (Campbell et al. 1995). Lobbying for changes in tort law led to many reform proposals over the last 30 years, and these were put forward and decided on in state legislatures. We want to understand whether there is a systematic partisan component to this process that can at least partly explain the patchwork of tort reforms across U.S. states.

\footnotetext{
${ }^{1}$ Tort law deals with situations where one party's behavior causes another party to suffer a loss or harm. The law allows the party who is harmed to recover its loss. The aims of tort law, however, are not confined to insurance and compensation but damages may also be awarded for deterrence. The economic analysis of tort law emphasizes this latter aim based on the argument of an efficient distribution of risk in order to provide optimal incentives for cost minimizing precautions in the presence of transaction or litigation costs (for basic contributions, see Coase 1960. Calabresi 1970 and Shavell 1987).

${ }^{2}$ Estimates of the total transactions generated by the American tort law system amount to USD 265 billion in 2010 ; i.e., $1.82 \%$ of GDP. This indicates a decline from $2.21 \%$ of GDP (or USD 246 billion in current prices) in 2003 (Towers Watson 2012). Expenses in terms of fees and administrative costs, i.e., money not flowing as compensation to injured parties, account for more than half of the amount (U.S. Council of Economic Advisers 2004).

${ }^{3}$ The most important player is the American Association for Justice (AAJ), formerly the Association of Trial Lawyers of America (ATLA).

${ }^{4}$ From the numerous business groups involved in pushing reforms, the U.S. Chamber of Commerce is a prominent one. Many businesses support the American Tort Reform Association (ATRA).
} 
In this empirical analysis, we are particularly aiming at identifying any partisan effect that goes beyond potential underlying voter preferences for reforms in statutory tort law. One might well argue that greater support for and a stronger presence of the Republican Party in the legislature or when holding the governorship reflects voters' demand for tort reforms. Indeed, if reforms were to be found more likely under a Republican majority or governor, this would be evidence for a systematic influence of politico-economic forces. However, the evidence would not allow distinguishing between underlying voter preferences and a specific partisan effect. In the empirical analysis, we therefore, first, take citizens' general political attitudes into account when we test whether at any point in time a reform restricting tort liability in a U.S. state is introduced earlier with a stronger representation of Republicans in state politics. Second, we concentrate on the enactment of reforms when either party holds the legislative majority or the governorship with a close margin.

In our analysis of the reform process, we refer to the area of medical malpractice 5 We analyze data from the Database of State Tort Law Reforms (Avraham 2011a), which contains the most prevalent medical malpractice tort reforms between 1980 and 2008. Avraham (2011a) distinguishes between eleven different types of non-wrongful death medical malpractice tort reforms. We concentrate on the five types of reforms that are most intensively discussed in the literature; i.e., caps on punitive damages, punitive evidence reform, caps on non-economic damages, reforms of the collateral source rule and reforms of the joint and several liability rule. Our empirical strategy combines the idea of regression discontinuity studies based on close electoral outcomes with methods of survival analysis in order to empirically disentangle the politico-economic forces outlined above. Specifically, we estimate different specifications of semi-parametric proportional hazards models to calculate the effects of a Republican majority in the legislature as well as of a Republican governor on the hazard of tort reform passage, given the relative strength of the parties. This approach allows us to exploit the cross-sectional as well as the longitudinal variation in the data. We adopt a broad view of the reform process and look jointly at repeated reform events across different domains of medical malpractice tort law in each state.

We find that the reform process overall can be well described as a partisan fight between the Republicans and the Democrats, whereby a narrow Republican majority in a state's lower house is associated with a 50 to 150 percent higher instantaneous risk of reform enactment in any given year than a narrow Democratic majority. A multiplicative effect on the hazard that is larger than one is also estimated for Republican governors. However, the result is not statistically significant in all specifications. These effects hold independently of differences in the liability risk in the early 1980s, the political orientation of the population, and

\footnotetext{
${ }^{5}$ The other main areas are automobile accident law and product liability law.
} 
a number of other control variables. Furthermore, the evidence regarding the reform process at the macro level complements recent evidence on individual voting behavior on single tort reform proposals in various tort areas at the micro level. In Matter and Stutzer (2015), we find that Republicans are more likely and lawyer-legislators less likely to support reforms that restrict tort litigation.

This paper proceeds as follows. Section 2 discusses related work and reviews the literature on the consequences of (medical malpractice) tort reforms. In Section 3, we develop our politico-economic hypotheses regarding the legislative reforms in medical malpractice law. Section 4 outlines the empirical strategy based on survival analysis. The data for the empirical tests is described in Section 5 . Section 6 presents the results. Concluding remarks are offered in Section 7 .

\section{Related work and literature review}

We see our analysis as a complement to the literature on the consequences of alternative tort regimes and specific regulations. This literature has accumulated an interesting body of empirical findings, whereby the design of tort law is considered an exogenous factor.

It might thus be interesting to understand the conditions under which reforms are more likely. Moreover, reform enactments might well reflect specific politico-economic constellations that affect the legal environment in areas that are complementary to tort law. We are not aware of many systematic empirical analyses that try to explain the reform process so far. In related work, Klick and Sharkey (2009) examine the effect of jury awards on the passage of damage caps. They find no statistical relationship between these two factors. Miceli and Stone (2013) restrict their study to caps on punitive damages and focus on parametric hazard analysis. They observe a positive relationship between legal services employment and the hazard of cap enactment as well as that rather liberal states have a lower hazard of cap enactment. In our analysis, we look at reforms in five domains and concentrate on semi-parametric proportional hazards models, since the underlying distribution of the baseline hazard is theoretically undetermined.

The literature on the consequences of alternative tort regimes is much richer. For example, Avraham (2007) investigates the impact of six different types of tort reforms on the frequency, size and number of total settlements in medical malpractice cases between 1991 and 1998. He shows that caps on pain and suffering damages and limitations on joint and several liability reduced the number of annual damage payments, while the periodic-payment reform and, again, caps on pain and suffering damages reduced average awards. Paik et al. (2013), taking the gradual phase-in of damage caps into consideration, find strong negative effects of this reform on claim rates as well as on payout per claim. Moreover, they present evidence suggesting that 
claim rates specifically decrease in claims with larger payouts and that stricter caps are associated with larger effects. Conversely, Donohue and Ho (2007) find no evidence that caps on pain and suffering as well as on punitive damages had any effect on the number of claims, using (nonparametric) randomization inference with differences-in-differences. Viscusi and Born (2005) find that medical malpractice reforms reduced the losses and increased the profitability of insurance companies. Klick and Stratmann (2007) show, using a tripledifferences design to capture potential endogeneity of the passage of medical malpractice reforms, that caps on non-economic damages positively affect the number of doctors in high-risk specialties in a state. Additionally, Helland and Showalter (2009) find evidence that an increase in expected liability costs is associated with a decrease in a physician's hours worked. Rubin and Shepherd (2007) study the impact of different types of tort reforms on non-motor-vehicle accidental death rates and present significant positive as well as negative effects, depending on the type of tort reform. While non-economic damages caps, punitive evidence reform, product liability reform as well as prejudgment interest reform significantly decrease the number of accidental deaths, collateral source rule reform significantly increases the number of accidental deaths. Building on these results, Rubin and Shepherd (2008) as well as Shepherd (2008) show that the non-motor-vehicle accidental death rates of women and men are affected differently by malpractice tort reform; i.e., the death rate for women is increased, while that for men is decreased. Carvell et al. (2012) provide evidence that joint and several liability tort reforms have been accompanied by reductions in the non-auto, non-overdose accidental death rate. However, Frakes and Jena (2014) find only small and statistically insignificant effects of changes in malpractice pressure (in terms of non-economic damages caps) on different measures of health care treatment quality. Similarly, Sloan and Shadle (2009) conclude, based on the analysis of eight different reform types, that neither medical decisions nor patient outcomes are systematically affected by tort reforms. Finally, Kessler and McClellan (1996) and Currie and MacLeod (2008) assess the effect of malpractice reform on the practice of defensive medicine. Kessler and McClellan (1996) find that reduced liability pressure leads providers to reduce medical expenditures in treatment of serious heart disease without substantial negative effects on the rate of mortality. In a similar vein, Currie and MacLeod (2008) investigate whether certain types of tort reform affect the choice of birth procedures and, related to this, the health outcomes of mothers and their infants. They find that joint and several liability reforms reduce the probability of cesarean delivery as well as complications of labor and delivery, while damage caps increase the probability of additional procedures and complications. 


\section{Politico-economic determinants of reforms in medical malpractice law}

\subsection{The evolution of medical malpractice tort law}

The judicial process in the United States brought about a common law tort regime during the 1960s and 1970s that strengthened the position of victims and their (plaintiff) lawyers. These legal changes allowed plaintiffs to sue for high non-compensatory (punitive) damages and lawyers to share in the awards. A large popular and scientific literature controversially discusses the merits and flaws of this system. The same holds for the assessment of the backlash that occurred when defense interests from industry and the medical profession started lobbying in state legislatures for reforms to curb the tort system (Rubin 2005). Five types of reforms are of particular importance:

1. Caps on punitive damages: Statutes that either ban punitive damages outright or limit them to a maximum amount.

2. Punitive evidence reform: Statutes of this reform-type require a higher burden of proof for recovery of punitive damages. Such statutes often require the plaintiff to present "clear and convincing" evidence that the defendant acted maliciously.

3. Caps on non-economic damages: Reforms in this domain include statutory limits to damage awards for psychological losses such as damages for pain and suffering.

4. Collateral source rule reforms: Under the collateral source rule, defendants were not allowed to present evidence at trial proving that a plaintiff had already been compensated for a loss from another source of remuneration; e.g., her insurance. Statutes that abolish or limit this rule are subsumed in this reform type.

5. Joint and several liability reforms: If the harm is caused by two or more parties, the joint and several liability rule enables plaintiffs to sue any of these for the whole amount of damages, regardless of their relative responsibility. Reforms considered in this category usually limit the rule of joint and several liability in such a way that any party causing harm can only be sued for its proportion of fault.

Figure 1 illustrates the reform process in terms of the enactment of these five reform types across the U.S. states during the period of observation in our study; i.e., 1980 to 20086 In all these law changes, reformers

\footnotetext{
${ }^{6}$ More descriptive details on the tort reform process are presented in Section 5.
} 
understand that the transaction value of tort cases, and therefore liability pressure, is reduced. We do not aim at assessing the pros and cons of these reforms for the consumers and patients 7 We rather want to gain a better understanding of the reform process as such, in particular, the role of political parties as brokers of (specific) interests within state politics. Is there a pattern in the patchwork of legislative tort reforms that is systematically related to political conditions over and above the economic ones in the U.S. states?

Figure 1: Number of reforms enacted across the U.S. states between 1980 and 2008
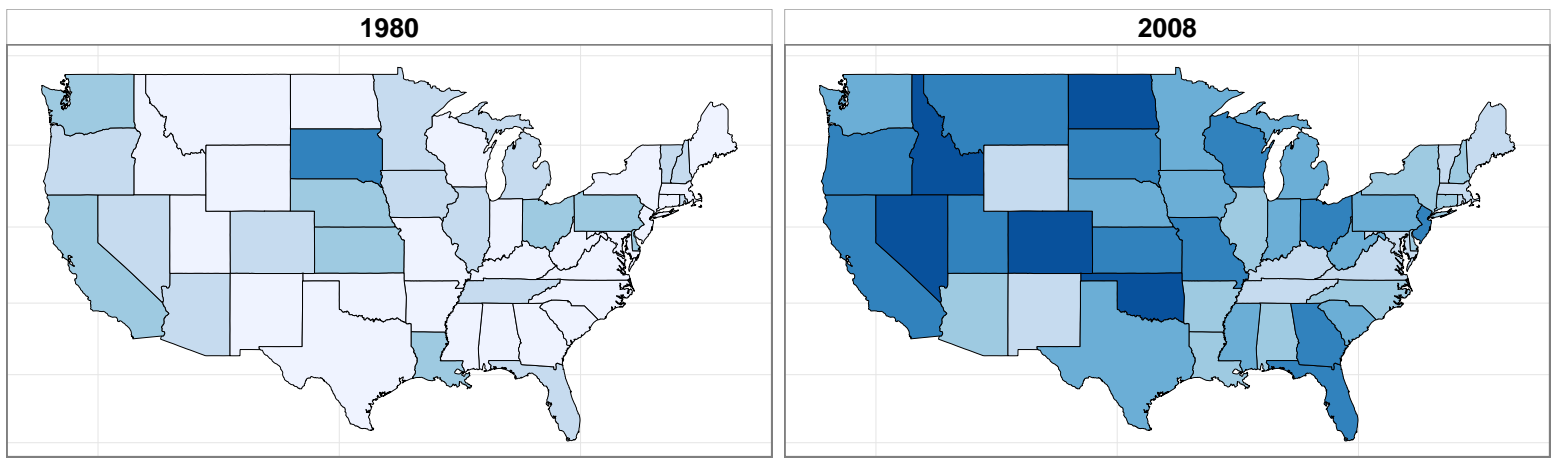

Number of reforms enacted $\square 0 \square 1 \square_{2} \square_{3} \square_{4} \square^{5}$

Data source: Avraham (2011).

\subsection{Basic hypotheses}

We structure the various forces that affect the tort reform process according to three basic hypotheses. First, there is the perspective that reforms reflect legal changes towards more efficient arrangements. Tort reforms are more likely to come about where there is a particular reform pressure. In states with a higher liability risk for physicians, we thus expect tort reforms to be more likely at any point in time. We think of this force as one that is necessary to take into account in order to approximate to ceteris paribus conditions for the other factors.

Second, we might start from the benchmark that legislative tort reforms reflect voters' preferences due to electoral competition in the democratic process. For instance, in states where more people share political attitudes that favor individual responsibility on the part of consumers, tort reforms are expected to be more likely. Thereby, pressure from voters may affect policy reforms or citizens may directly elect candidates with particular policy preferences (see Lee et al. 2004 for a discussion). However, this hypothesis is difficult to test

\footnotetext{
${ }^{7}$ Key references to the evaluation literature are provided in Section 2
} 
directly, as indicators on people's attitudes towards the tort regime in their state are rare. Instead, we rely on the general political attitudes in a state as reflected in their representatives' voting behavior in Congress 8 Furthermore, citizens' interests are notoriously difficult to organize because of the free rider problem (Olson 1965) and a strong hypothesis is thus not warranted.

Third, there is the view of politics as a platform where parties organize the brokerage of different interests. Tort reforms are understood to be the result of a lobbying process involving competing well-organized interest groups. In particular, business associations and associations of physicians are expected to engage in spurring the reform process in order to reduce the likelihood and magnitude of damage awards that their members have to pay or insure against. Opposition is expected from lawyers who benefit substantially from the litigation business. The demand for tort lawyers and thus their income opportunities increase with the amount and the value of tort litigation as well as with the cost of litigation; i.e., with the complexity of the tort system. Therefore not only do plaintiffs' lawyers benefit professionally and financially from an increased demand for their services, but also defense lawyers (Olson 2003) and transactions lawyers.

In the context of U.S. tort reforms, the lobbying process is often described as a battle, as it has become a partisan issue, with the Democrats fighting against reforms and the Republicans fighting in favor of reforms. This involves the members of the legislatures as well as the governors, who play an important role in the appointment of judges in many states and who might also influence the legislative reform process with their veto right. The partisan orientation is often explained by the large financial support that the Democrats receive from trial lawyer associations (Zywicki 2000). However, this is not an obvious link, as lobby groups do not want to depend on members of one party alone, but, rather, rely on logrolling and gaining support across the political spectrum. Furthermore, while the Republicans' idea of a laissez-faire economy surely agrees with product liability reforms that aim to remove the burden of potential damages from the manufacturing industry, it is not clear that the same rationale and political ideology also applies to medical malpractice, particularly when one considers that the concept of tort law also represents the "[...] principle of personal responsibility for wrong doing, and this is normally a core conservative value" (Sugarman 2006: 1105).

Overall, it is difficult to discriminate between the hypothesis emphasizing voter preferences and that highlighting special interests. The forces in both cases are difficult to measure and agents in favor of reforms tend to be more likely to support the Republicans. In order to get at the partisan channel representing an amalgam of ideology and special interests, we focus on close electoral outcomes.

\footnotetext{
${ }^{8}$ Specifically, we draw on the voting records that are summarized in the so-called DW-Nominate scores (first dimension) and reflect a conservative to liberal score of the representatives.
} 


\section{Empirical strategy}

\subsection{Identification of a partisan effect}

In order to disentangle a specific partisan effect from correlated political forces, such as the preferences in the constituency, we exploit the idea suggested in studies relying on regression discontinuity designs (RDD) based on close electoral outcomes (Lee 2001, Lee et al. 2004, Pettersson-Lidbom 2008, Ferreira and Gyourko 2009, Lee and Lemieux 2010, Albouy 2013). The intuition behind our approach is simple. If political and/or economic forces from the constituency drive tort reforms and are simultaneously correlated with a stronger Republican representation in U.S. states, we would expect the relationship between the risk of reform enactment and the share of Republicans in a legislature (or a Republican Governor) to be positive, monotonic and continuous. If, however, Republican party politics itself is a relevant driver of reform enactment, a narrow Republican majority would lead to a disproportional increase in the risk of reform enactment compared to a narrow Democratic majority. In other words, the probability of tort reform enactment as a function of the Republican vote share would be discontinuous at the $50 \%$ threshold. Assuming parties do not have exact control over electoral outcomes, such a partisan effect can be identified by comparing states just below the $50 \%$ cutoff $c$ with states just above this cutoff. Formally, the partisan effect $\tau$ can be expressed as

$$
\tau=\lim _{x \uparrow c} E\left[\text { Enactment }_{i t} \mid X_{i t}=x\right]-\lim _{x \downarrow c} E\left[\text { Enactment }_{i t} \mid X_{i t}=x\right],
$$

where Enactment En $_{i t}$ is an indicator variable that is equal to one if state $i$ enacts a reform at time $t$ and $X_{i t}$ is the Republicans' winning margin (Republicans' vote share minus Democrats' vote share). The simplest approach to estimate (1) is to compute the mean difference in a range of $X_{i t}$ above and below the threshold. However, if the vote share of Republicans is correlated with the risk of reform enactment, this mean difference would be biased, as $E\left[\right.$ Enactment $\left._{i t} \mid X_{i t}=x\right]$ would have a non-zero slope. A practical solution to this problem is to estimate a simple linear probability model of the form

$$
\text { Enactment }_{i t}=\tau D+g\left(X_{i t}\right)+Z^{\prime} \beta+\epsilon_{i t}
$$

where $D$ is an indicator variable equal to one if $X_{i t}>c ; g\left(X_{i t}\right)$ is a linear function or a polynomial of the Republicans' winning margin $X_{i t} ; Z$ is a matrix of control variables; and $\epsilon_{i t}$ is an idiosyncratic error term ${ }^{9}$

\footnotetext{
${ }^{9}$ Note that the inclusion of a polynomial or spline function of the Republicans' winning margin most flexibly ensures that an increase or decrease in the risk of reform enactment around the threshold is not misinterpreted as a discontinuity when, in fact, it simply represents a nonlinear relationship between $X_{i t}$ and Enactment $t_{i t}$. However, high-order polynomials might result in misleading estimators for the discontinuity parameter (Gelman and Imbens 2014). We thus only use polynomials of order 2 in our analyes.
} 
Model (2), however, ignores the timing of reform enactments and thus important information in our data. As we want to study the forces accelerating the reform process or, in other words, to investigate the factors increasing or decreasing the instantaneous risk of reform enactment in a state, our empirical strategy relies on survival analysis. The focus thus lies on the duration $t$ that a state is at risk of tort reform enactment, before the reform is actually introduced. Stated technically, we are interested in the hazard rate of tort reform enactment $\lambda(t)$, which can be described as the instantaneous risk of reform enactment at time $t$ given the reform has not yet been enacted. Assuming continuous time, this can be written formally as

$$
\lambda(t)=\frac{f(t)}{1-F(t)}=\frac{f(t)}{S(t)}
$$

where $\lambda(t)$ is the hazard rate of tort reform enactment, $f(t)$ is the density function of durations to enactment, $F(t)$ is the probability distribution of durations to enactment and $S(t)$ is the survivor function of durations to enactment.

In sum, in order to assess a partisan effect on the hazard rate of reform enactment, we apply the RDD approach outlined above to the Cox proportional hazards model (Cox 1972, hereafter Cox model). Formally, the Cox model can be expressed as

$$
\lambda\left(t \mid X_{t}\right)=\lambda_{0}(t) e^{\beta^{\prime} X_{t}}
$$

where $\lambda\left(t \mid X_{t}\right)$ is the hazard rate of reform enactment given $X$ at time $t ; \lambda_{0}(t)$ is the underlying baseline hazard of reform enactment; $\beta$ is a vector of regression coefficients, and $X_{t}$ a matrix of explanatory factors. The Cox model allows us to estimate $\tau$ as a multiplicative effect on the baseline hazard of tort reform enactment $\lambda_{0}(t)$ by exploiting the information of the timing of reforms. The goal is thus to apply a statistical procedure that allows us to make statements like: "States just above the threshold of $50 \%$ Republican votes in the gubernatorial elections had a $x \%$ higher hazard of reform enactment than states just below this threshold."

\subsection{The Cox proportional hazards model in an RDD context}

As the use of Cox models in an RDD context is rather novel in the economic literature, we guide the reader step by step through our empirical approach (see Bor et al. 2014 for a general introduction to the application of proportional hazards models in an RDD context, as well as Pintoff 2004 for an early application in economics). In addition, we illustrate the properties of and intuition behind the Cox model in an RDD context with a Monte Carlo study presented in the Appendix to this paper.

First, we express the right-hand side of (1) as a difference of expected hazard rates given the Republicans' 
winning margin

$$
\lim _{x \uparrow c} E\left[\lambda\left(t \mid X_{i t}=x\right)\right]-\lim _{x \downarrow c} E\left[\lambda\left(t \mid X_{i t}=x\right)\right] .
$$

By inserting the right-hand side of (2) into (4) we can rewrite $(5)$ as

$$
\lim _{x \uparrow c} E\left[\lambda_{0}(t) e^{\left(\tau D_{=1}+g\left(X_{i t}\right)+Z^{\prime} \beta\right)}\right]-\lim _{x \downarrow c} E\left[\lambda_{0}(t) e^{\left(\tau D_{=0}+g\left(X_{i t}\right)+Z^{\prime} \beta\right)}\right]=e^{\tau} .
$$

In the context of hazard modeling, we can thus estimate the partisan effect as the exponentiated estimated coefficient $\hat{\tau}$ from a Cox model of the form

$$
\lambda\left(t \mid X_{i t}=x\right)=\lambda_{0}(t) e^{\left(\tau D+g\left(X_{i t}\right)+Z^{\prime} \beta\right)} .
$$

By fitting (7) for a range of $X_{i t}$ around the threshold of the Republican's winning margin of 0 (i.e., $50 \%$ of Republican votes), we can interpret the estimated hazard ratio $e^{\hat{\tau}}$ as the average partisan effect on the hazard of tort reform enactment. We thus identify the partisan effect based on a subset of states with generally competitive elections. Note that these states, in the context of hazards modeling, need to remain in the sample throughout the whole time period of the analysis. As we are interested in the timing of reform enactments, we cannot include a particular state just for a few years due to one narrow election and then exclude it again. The sample thus consists of states that were generally contested throughout a certain period of time during which many reforms were enacted.

Specifically, we select states that never exceed a certain bandwidth around the threshold throughout the time-frame under analysis. Figure 2 illustrates this point. From the three depicted states only state A fulfills the requirement for the whole observation period. State C only fulfills it for the first 13 years and state B given the exemplary bandwidth of 12 percentage points - never fulfills the requirement. 
Figure 2: Selection of subsamples

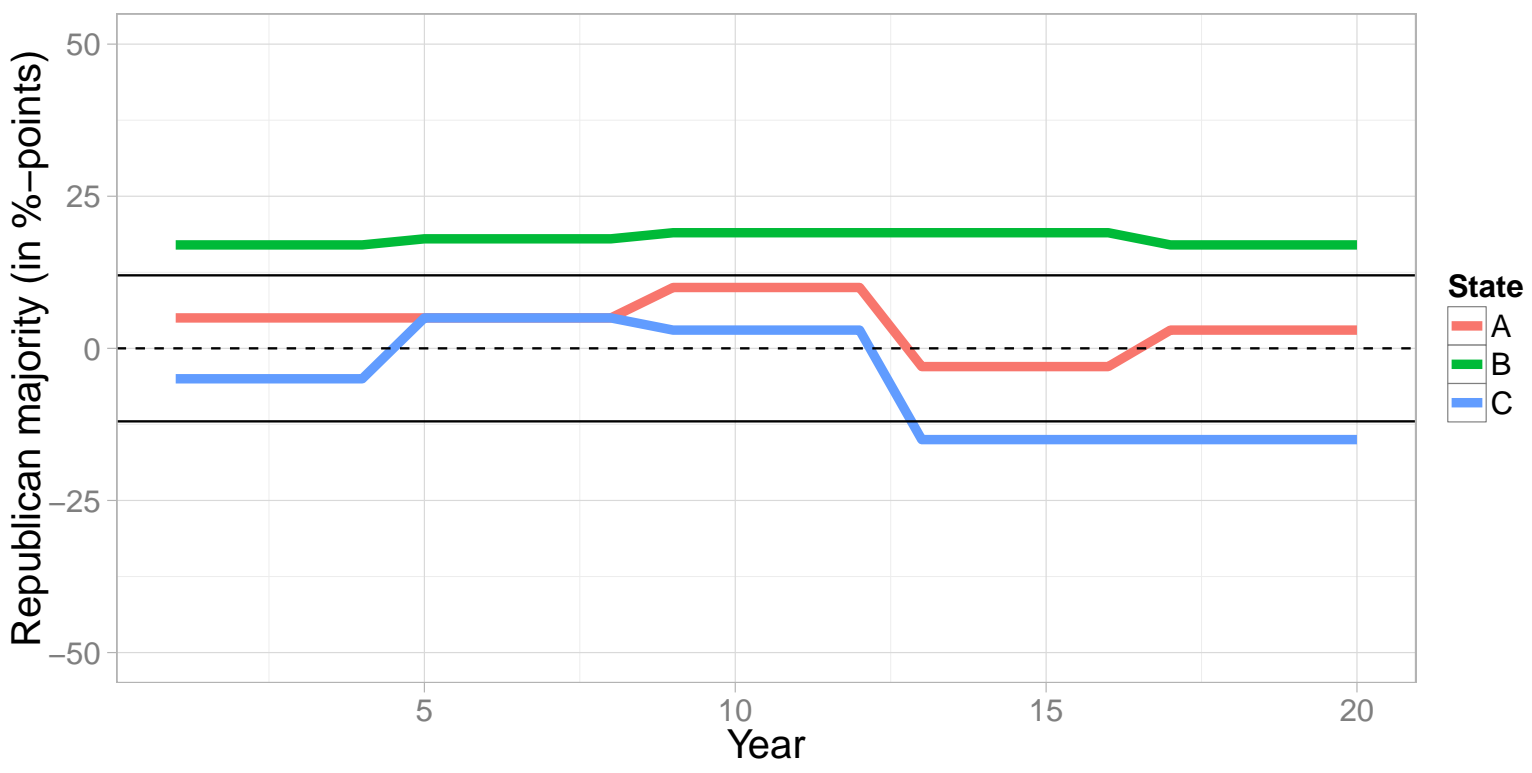

\subsection{Estimation with repeated events}

Since the underlying real-world distribution of durations to tort reform enactment is unknown and since the literature lacks - to our best knowledge - any theoretical approach for approximating this distribution, we do not parametrize the underlying baseline hazard $\lambda_{0}(t)$. Instead, we rely on Cox' partial-likelihood method (Cox 1972) to set up and maximize the log-likelihood for $27 \sqrt{10}$ The advantage of this approach is that we do not need any assumption about the underlying distribution of $t{ }^{11}$ The downside of this approach is its lower efficiency, as it can only take the order of events (reform enactments) into account, but not their distribution.

We take a general view of the reform process by looking at reform events as such. A single state may thus experience the event of passing a reform several times. This allows for identification of the partisan effect as a driving force of the overall reform process. Our empirical model is essentially the same as (7). However, the dataset is structured differently than in a standard Cox model. All states stay in the risk set for the entire observation period whether they enacted one or several reforms or no reform at all ${ }^{12}$

We apply two distinct techniques to analyze the data in this structure. First, we estimate a model with the approach suggested by Andersen and Gill (1982), often referred to as the counting process approach or the

\footnotetext{
${ }^{10}$ In the case of tied events, such a model cannot be estimated directly. Since different states happen to enact some reforms in the same year, this is an issue in our study. We use the Efron method to deal with this problem (see Therneau and Grambsch 2000 for a discussion of handling tied events in a Cox model).

${ }^{11}$ In this respect, our empirical strategy diverges significantly from the one applied by Miceli and Stone (2013), who rely on the assumption that $t$ is Weibull-distributed.

${ }^{12}$ Reform bills that included more than one issue are treated as one reform enactment in a given year.
} 
independent increment model (IIM; Therneau and Hamilton 1997), which is probably the simplest approach to estimate a Cox-like model with repeated events. It is important to note, though, that this implies the assumption that reform enactments are independent of each other, which furthermore implies that the risk of reform enactment for any state is not affected by any earlier reform in this state. This assumption is rather problematic because, for example, the passage of one reform might reduce the pressure for additional reforms. Therefore, we also apply the 'conditional' approach suggested by Prentice et al. (1981) as an alternative ${ }^{13}$ The conditional model $(\mathrm{CM})$ takes the sequence of events into account and is therefore considered to be more efficient and thus often preferable when analyzing repeated events data (Box-Steffensmeier and Zorn 2002). The CM approach exploits the sequence of events by using exactly the same data layout as the IIM but applies a stratified Cox model instead of a standard Cox model. The stratum variable is defined by the number of events experienced. Hence, a state is in stratum 1 when it is at risk of experiencing the first reform enactment. As soon as the first reform has been enacted, the state changes to stratum 2. We apply the CM approach for all estimations focussed on the identification of a partisan effect.

A potential problem with repeated events is the lack of independence within states. From the same state, two or more reform enactments may be included in the data set and be affected by the same unobserved factors leading to correlations among them. Therefore, the assumed correlation structure might be misspecified. We compute robust standard errors (clustered at the state level) to adjust for this potential misspecification.

\section{Data}

\subsection{Tort reform data}

Information on tort reforms for our empirical analysis comes from the Database of State Tort Law Reforms (DSTLR 3rd, Avraham 2011a). This dataset contains the most prevalent medical malpractice reforms between 1980 and 2008. It has been updated and improved several times over the last few years ${ }^{14}$ Since a large variety of reforms have been passed, there are many ways to code such data for analysis. In this paper, we rely mainly on the coding suggested by Avraham (2011a) ${ }^{15}$ In particular, we use the dataset version 'DSTLR 3rd (clever)' in our main analysis, from which reforms that were identified by Avraham (2011a) as having no impact were removed. In other words, reforms that are not restrictive in practice, such as caps that are very high or only applicable in certain circumstances, are excluded from this dataset. Nevertheless, for all of our analyses, we diverge and adjust the coding in two directions. First, we exclude all reforms that have been enacted by a

\footnotetext{
${ }^{13}$ This method is also called the stratified counting process approach (Kleinbaum and Klein 2005).

${ }^{14}$ In our dataset, we have incorporated all further improvements to DSTLR 3rd published in Avraham (2011b).

${ }^{15}$ See Avraham 2011b for a detailed description of how the reform data was coded.
} 
judicial decision (reforms by common law). We thus retain only the reforms that are written in the civil code or statutes of a state ${ }^{16}$ Second, we make sure that the timing of each reform is coded according to the year of actual enactment 17

The information base that we exploit thus consists of the year(s) of actual enactment of tort reforms for five different types (as described in Subsection 3.1) across all U.S. states except Nebraska ${ }^{18}$ From this information, we compute the durations to reform enactment by defining the year 1980 as the starting point of the observation period. The choice of 1980 as the beginning of the observation period is somewhat arbitrary, because it implies the assumption that all states only started to be at risk of reform in that year. Making such an assumption is hardly avoidable when analyzing the passage of policies with proportional hazards models. Unlike in other applications of these methods (such as the analysis of unemployment spells), it is per se unclear when the individual (in our case a state legislature) enters the risk set. A prominent case of policy innovation by one state would be a sound reason to set the beginning of observation for other states. One could argue that the frequently cited tort reforms enacted by the California legislature in 1975 represent such a prominent case of policy innovation in the context of tort law. However, this would ignore the fact that some states' constitutions or common law contain liability limiting rules, such as caps on punitive damages that date back to the 19th century (Avraham 2011b). U.S. states have thus been at risk of reforming their law of torts since they came into existence 19

We count 20 reforms defining caps on punitive damages, with Illinois and Wisconsin being the first states in 1985. Reforms involving punitive evidence are observed in 23 states, for the first time in Indiana in 1984. Caps on non-economic damages are coded for 21 states, beginning with Colorado, Kansas, Maryland, Minnesota and Missouri in 1986. Collateral source rule reforms started in New York in 1984, and have been enacted in 19 states so far. Finally, for joint and several liability reforms, we observe reforms in 31 states, with Louisiana being the first in 1980. Figure 3 shows the distribution of the five types of reforms over time. While reforms of the collateral source rule and joint and several liability were enacted relatively early during the first big wave of reforms in 1985/1986, the enactments of other types of tort reform are distributed more

\footnotetext{
${ }^{16}$ Table A1 in the Appendix gives an overview of the states and reforms included in each analysis. Additionally, a list with the reforms identified as enacted by a judicial decision and thus excluded from the dataset can also be found in the Appendix.

${ }^{17}$ This was necessary because the original coding treats reforms that were enacted after June in year $t$ as belonging to the next calendar year $t+1$ (Avraham 2011b).

${ }^{18}$ We exclude data on Nebraska from the analysis due to the lack of information on party strength in its nonpartisan legislature.

${ }^{19}$ However, there are some reasons to set 1980 as the beginning of observation in our study. First, when setting the beginning of the observation period to any year before 1980, we risk losing accuracy in the reform data. Although DSTLR also mentions reforms that were enacted before 1980, it is much more complete and accurate for the time after. The same is true for some of our explanatory variables mentioned below. Second, our approach is in agreement with Klick and Sharkey (2009:8), who argue that "there is no particularly principled way to date the beginning point of when a state could have possibly adopted a punitive damage cap" and set the beginning of observation also according to the availability of data. Miceli and Stone (2013:117) strategically choose 1981 as the starting point in their analysis "to coincide with the year in which the California Supreme Court rendered the Grimshaw decision". We do not follow this argumentation, because Grimshaw was a case of product liability tort law, while the data we use mainly contains reforms of medical malpractice tort law.
} 
equally over time.

Figure 3: Distribution of tort reform enactments over time

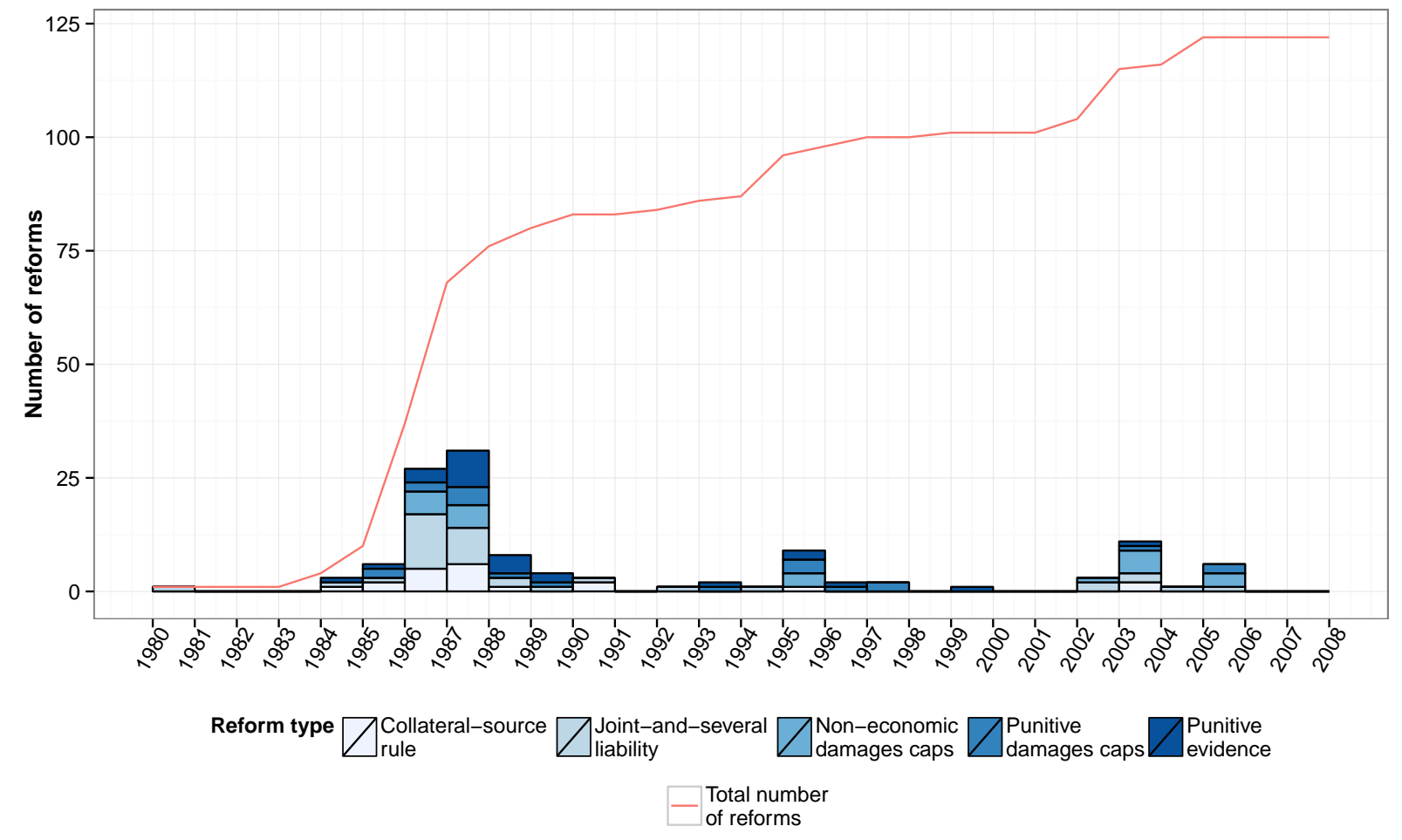

Data source: Avraham (2011a).

\subsection{Explanatory variables}

Our main explanatory variables are the Republicans' majority margin in the legislative assemblies and the Republicans' winning margin in gubernatorial elections, respectively. The latter is computed based on the official gubernatorial election data provided by the Inter-University Consortium for Political and Social Research (1984) for the years 1980 to 1990 and from Leip (2013) for the years 1991 to 2008. The percentage of Republicans in a state's lower and upper house, respectively, are taken from the State Politics and Policy Quarterly State Dataset (Lindquist 2007) and for recent years from the U.S. Census Bureau.

In the case of the legislature, our assignment variable $X_{i t}$ for every year $t$ and state $i$ is the Republicans' current majority margin in the respective assembly computed as the percentage of Republican seats in the assembly minus 50 percentage points.

In the case of governors, our assignment variable $X_{i t}$ for every year $t$ and state $i$ is the Republicans' winning margin in the last gubernatorial elections computed as the difference between the percent of Republican votes 
minus the percent of Democratic votes ${ }^{20}$ The treatment dummy $D$ in the case of governors is equal to one if the current governor is Republican.

The central underlying assumption of our identification strategy is that parties have imprecise control over the election outcomes (i.e., the assignment variable). This implies continuity at the threshold. McCrary (2008) suggests an intuitive test of whether there is a discontinuity in the aggregate distribution (i.e., the density) of the assignment variable. We present the test results as well as a graphic illustration of the assignment variable's aggregate distribution in Figure 4.

Figure 4: Aggregate distributions of Republican winning margins

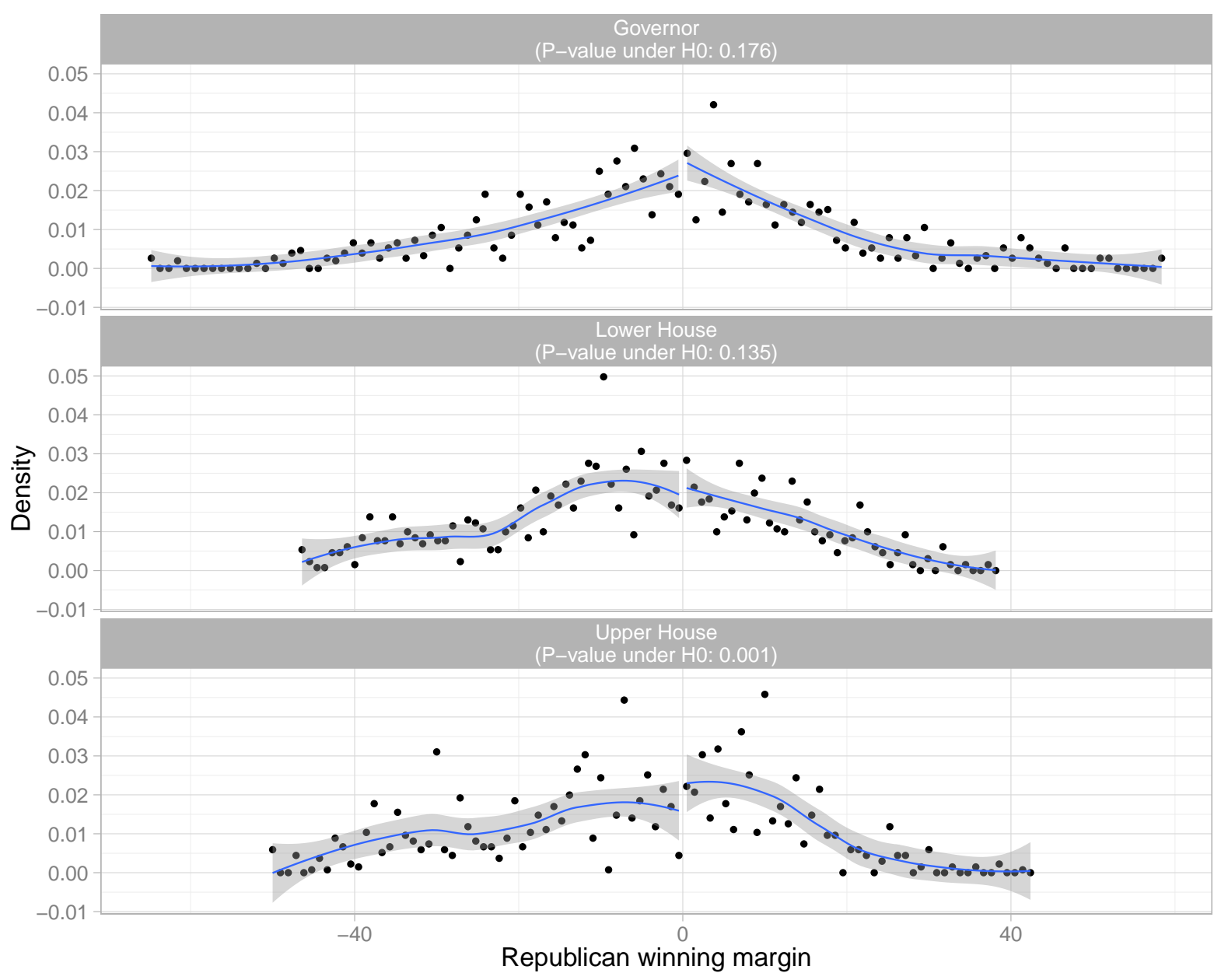

Notes: The panel shows density plots of the three aggregate assignment variables and results of the test suggested by McCrary (2008). Data sources: Inter-University Consortium for Political and Social Research (1984), Leip (2013), and Lindquist (2007).

\footnotetext{
${ }^{20}$ In nine states some of the gubernatorial elections were not decided between a Democrat and a Republican. These states are excluded from the analysis.)
} 
The p-values indicated in Figure 4 stand for the probability of observing this pattern in the data if the data generating process incorporates a continuous density of the assignment variable (H0; the null hypothesis in McCrary's test). For both the Republican winning margin in gubernatorial elections and the Republican majority margin in the lower houses, the null hypothesis of continuity cannot be rejected. However, in the case of the Republican majority margin in the upper houses, H0 is rejected. Any partisan effect estimated based on the upper house data must thus be interpreted with caution as it might simply result from the discontinuity in the assignment variable. We thus focus our analysis on the governor and the lower house.

In addition, we collected a series of state-level control variables that are included in some specifications. These variables involve a measure for the liability risk in 1983. It allows controlling for the reform pressure in a state in the early 1980s. Moreover, these variables capture the general political orientation of the electorate (DW-Nominate scores), the strength of interest groups (proxied by the health and legal sectors' share of gross state product), the level of income (real gross state product per capita), as well as the composition of the legislature (fraction of women and fraction of lawyer-legislators). Detailed information on each of these variables is presented in the Appendix. The inclusion of controls in an RDD context should not matter for the coefficients of interest (i.e., the estimation of a partisan effect at the threshold). Apart from checking the validity of the RDD approach, the inclusion of control variables is, however, useful as it potentially increases the efficiency of the estimator.

Table 1 shows some descriptive statistics for the main explanatory variables as well as the control variables used in our analyses.

\subsection{Sample selection}

The strategy used to identify a partisan effect relies on the selection of sub-samples containing states with generally contested elections. As explained in Subsection 4.2, we require that the election outcomes are within a certain bandwidth around the threshold throughout the time for which the analysis is undertaken. This selection and thus the feasibility of our empirical approach face some constraints that are inherent to the data we use. The narrower the bandwidth, the less likely it is that a certain state's election outcomes fulfill the requirement. However, if we restrict the analysis to a shorter time period fewer states and events are excluded.

In a supplementary analysis, we explored how our sample is affected by a bandwidth of $+/-15$ percentage around the threshold that states must not exceed for different time-frames for the years from 1980 to 2008. Thereby, we keep the beginning of the time-frames fixed at 1980 and vary the last year of the risk set. This investigation suggests that an analysis is well feasible with a moderate bandwidth of $+/-15$ percentage 
Table 1: Summary statistics for the independent variables (all reforms pooled)

\begin{tabular}{|c|c|c|c|c|c|c|}
\hline & Mean & Std.dev. & Median & Min. & Max. & Range \\
\hline Governor: Republican winning margin $>0$ & 0.48 & 0.50 & 0.00 & 0.00 & 1.00 & 1.00 \\
\hline Governor: Republican winning margin & -1.59 & 20.19 & -0.97 & -64.80 & 58.34 & 123.14 \\
\hline LH: Republican majority margin>0 & 0.36 & 0.48 & 0.00 & 0.00 & 1.00 & 1.00 \\
\hline LH: Republican majority margin & -5.97 & 17.32 & -5.63 & -46.72 & 37.14 & 83.86 \\
\hline UH: Republican majority margin $>0$ & 0.41 & 0.49 & 0.00 & 0.00 & 1.00 & 1.00 \\
\hline UH:Republican majority margin & -6.16 & 17.95 & -4.55 & -50.00 & 41.43 & 91.43 \\
\hline Republicans in legislature (\%) & 43.93 & 17.01 & 45.41 & 1.90 & 89.29 & 87.38 \\
\hline Attorneys in legislature (\%) & 16.43 & 8.53 & 16.33 & 0.00 & 51.67 & 51.67 \\
\hline Women in legislature (\%) & 17.83 & 8.38 & 17.14 & 0.82 & 42.35 & 41.53 \\
\hline GSP health industry (\%) & 5.73 & 1.57 & 5.61 & 1.04 & 11.35 & 10.31 \\
\hline GSP legal industry (\%) & 1.04 & 0.40 & 0.98 & 0.28 & 3.09 & 2.82 \\
\hline Liberal political orientation & -0.05 & 0.24 & -0.02 & -0.65 & 0.53 & 1.19 \\
\hline Liability risk (in USD 100) & 55.33 & 29.05 & 48.90 & 7.45 & 151.80 & 144.35 \\
\hline Real GSP p.c. (in USD 1,000) & 17.89 & 4.57 & 17.18 & 9.96 & 57.26 & 47.30 \\
\hline
\end{tabular}

Notes: $\mathrm{N}=1421$. The data consist of yearly observations for 49 U.S. states (We exclude data on Nebraska from the analysis due to the lack of information on party strength in its nonpartisan legislature.) from 1980 to 2008.

Data source: See main text in Section 5 and the data Appendix.

points in the case of the lower houses. The number of states varies between 19 (up to 1991) and 12 (for a sample up to 2008), while the number of events is strictly above 20. A sample restriction tends, however, not to be feasible in the case of gubernatorial elections. Here, no restriction of the time-frame leads to more than 13 events and 9 states. Moreover, for longer time-frames, the numbers of states and events is not greater than 5 , leaving basically no variation in the data to estimate a proportional hazards model ${ }^{21}$

\section{Results}

We present our results in three subsections. In order to arrive at a general understanding of the covariates of the state level tort reform process, we start with results from Cox models that include the average share of Republicans in a state's legislature as a continuous measure as well as an indicator for Republican governors (Section 6.1). Subsequently, we present the main analyses for the specific partisan effect of a legislature (lower house) dominated by a Republican majority (Section 6.2). We first show global estimates of the partisan effect for different specifications of model (7). Second, we present local estimates of the partisan effect for different time ranges as well as for different sample restrictions. Finally, we document the findings for the

\footnotetext{
${ }^{21}$ Details of these analyses are illustrated in Figure A2 in the Appendix. In addition, Table A4 in the Appendix lists the states remaining in each subsample.
} 
partisan effect in the case of a Republican governor (Section 6.3).

As there is no straightforward interpretation of the estimated coefficients in a Cox model, the tables report exponentiated coefficients. An exponentiated coefficient from a Cox model represents the multiplicative effect of the corresponding variable on the underlying baseline hazard (i.e. an exponentiated coefficient of 1.1 indicates that an increase of one unit in the corresponding variable ceteris paribus increases the hazard by $1.1-1=0.1=10 \%)$.

\subsection{Cox model estimates for the covariates of tort reform enactment}

Table 2 presents the findings for the malpractice tort reform process as a whole. Similar results are obtained for the unconditional Cox-like model with repeated events (IIM) in columns (1), (3), and (5) and the conditional model (CM) in columns (2), (4), and (6). Strikingly, liability risk, i.e., the indicator for reform pressure, is not statistically related with the hazard of overall reform enactment. The respective multiplicative effect on the hazard is close to 1 with z-values of the underlying coefficient ranging from -0.05 to -1.316 . This result fails to support our first hypothesis, but echoes the finding that large individual jury awards are not systematically related to tort reforms across states (Klick and Sharkey 2009).

In contrast, the political orientation in a state is systematically related to the adoption of reforms as indicated in specifications (1) and (2). For a one-standard-deviation more liberal orientation, the overall reform hazard is roughly $17 \%$ lower $(=(0.3-1) \times 0.24)$. Specifications $(3)$ and $(4)$ indicate that political orientation primarily works via the partisan composition of the state legislature and the party affiliation of the governor. If the fraction of Republicans in the legislature is higher by one percentage point, the hazard of reform is increased by $2.2 \%$. For one standard deviation in the strength of the Republican party, the corresponding effect on the hazard is about $34 \%(=(1.02-1) \times 17)$. If a Republican governor is in charge rather than a Democrat governor, the hazard of reform is around $46 \%$ higher. With these two party variables included, there is no independent effect of the general political orientation on the tort reform process. The evidence supports the idea that U.S. tort reforms at the state level are systematically affected by politicoeconomic forces. The finding is corroborated in specifications (5) and (6) where the correlated variable political orientation is not included. However, no conclusions can be drawn on whether the correlations for the party variables primarily reflect voter preferences (second hypothesis) or a partisan effect due to an amalgam of ideology and special interests (third hypothesis). We address this issue in the next section.

A substantial effect is also found for the fraction of women. With a one-percentage-point stronger presence of women in a legislature the hazard of reform is lowered by $3.8 \%$ to $4.2 \%$. This result indicates that female legislators have played an important role in opposing the ongoing malpractice tort reform process towards less 
liability. No systematic effects are found for the economic importance of the health and the legal industry, the share of attorneys in a legislature or gross state product per capita.

Table 2: Determinants of the overall malpractice reform process in U.S. states between 1980 and 2008

\begin{tabular}{|c|c|c|c|c|c|c|}
\hline $\exp$ (Coefficient) & (1) & $(2)$ & (3) & (4) & $(5)$ & (6) \\
\hline Liability risk (in USD 100) & $\begin{array}{l}1.000 \\
(-0.118)\end{array}$ & $\begin{array}{l}1.000 \\
(-0.050)\end{array}$ & $\begin{array}{l}0.996 \\
(-1.018)\end{array}$ & $\begin{array}{l}0.996 \\
(-0.839)\end{array}$ & $\begin{array}{l}0.995 \\
(-1.316)\end{array}$ & $\begin{array}{l}0.995 \\
(-1.013)\end{array}$ \\
\hline Liberal political orientation & $\begin{array}{l}0.345 * * \\
(-2.225)\end{array}$ & $\begin{array}{l}0.307 \text { ** } \\
(-2.218)\end{array}$ & $\begin{array}{l}0.635 \\
(-0.435)\end{array}$ & $\begin{array}{l}0.632 \\
(-0.390)\end{array}$ & & \\
\hline Republicans in legislature (\%) & & & $\begin{array}{l}1.020 * \\
(1.755)\end{array}$ & $\begin{array}{l}1.022 * \\
(1.659)\end{array}$ & $\begin{array}{l}1.023^{* * *} \\
(3.480)\end{array}$ & $\begin{array}{l}1.025 \text { *** } \\
(3.143)\end{array}$ \\
\hline Republican governor & & & $\begin{array}{l}1.460 * * \\
(2.034)\end{array}$ & $\begin{array}{l}1.455^{*} \\
(1.815)\end{array}$ & $\begin{array}{l}1.439 * * \\
(1.993)\end{array}$ & $\begin{array}{l}1.430 * \\
(1.800)\end{array}$ \\
\hline GSP health industry (\%) & & & $\begin{array}{l}1.024 \\
(0.148)\end{array}$ & $\begin{array}{l}0.970 \\
(-0.183)\end{array}$ & $\begin{array}{l}0.974 \\
(-0.220)\end{array}$ & $\begin{array}{l}0.928 \\
(-0.547)\end{array}$ \\
\hline GSP legal industry (\%) & & & $\begin{array}{l}1.517 \\
(1.269)\end{array}$ & $\begin{array}{l}1.666 \\
(1.240)\end{array}$ & $\begin{array}{l}1.563 \\
(1.412)\end{array}$ & $\begin{array}{l}1.677 \\
(1.285)\end{array}$ \\
\hline Attorneys in legislature (\%) & & & $\begin{array}{l}0.999 \\
(-0.091)\end{array}$ & $\begin{array}{l}1.001 \\
(0.075)\end{array}$ & $\begin{array}{l}0.998 \\
(-0.154)\end{array}$ & $\begin{array}{l}1.001 \\
(0.045)\end{array}$ \\
\hline Women in legislature $(\%)$ & & & $\begin{array}{l}0.959 \text { *** } \\
(-2.813)\end{array}$ & $\begin{array}{l}0.962 \text { ** } \\
(-2.133)\end{array}$ & $\begin{array}{l}0.958 \text { *** } \\
(-2.767)\end{array}$ & $\begin{array}{l}0.961 * * \\
(-2.142)\end{array}$ \\
\hline Real GSP p.c. (USD 1,000) & $\begin{array}{l}0.952 \\
(-1.383) \\
\end{array}$ & $\begin{array}{l}0.966 \\
(-0.969) \\
\end{array}$ & $\begin{array}{l}0.979 \\
(-0.473) \\
\end{array}$ & $\begin{array}{l}0.978 \\
(-0.452) \\
\end{array}$ & $\begin{array}{l}0.971 \\
(-0.631) \\
\end{array}$ & $\begin{array}{l}0.971 \\
(-0.590) \\
\end{array}$ \\
\hline No. of observations & 1421 & 1421 & 1421 & 1421 & 1421 & 1421 \\
\hline No. of events & 92 & 92 & 92 & 92 & 92 & 92 \\
\hline Logrank test $(p)$ & 0.06 & 0.094 & 0.005 & 0.009 & 0.008 & 0.014 \\
\hline Approach & IIM & $\mathrm{CM}$ & IIM & $\mathrm{CM}$ & IIM & $\mathrm{CM}$ \\
\hline
\end{tabular}

Notes: Cox-like proportional hazards models with repeated events. Specifications (1), (3), and (5) are based on an independent increment model. Specifications (2), (4), and (6) are based on a conditional model. Standard errors are clustered at the state level. Z-values of the coefficients are in parentheses. Statistical significance: $* 0.1>\mathrm{p}>0.05$, ${ }^{* *} 0.05>\mathrm{p}>0.01$ and $* * * \mathrm{p}<0.01$. No. of observations reflects total state-year observations at risk (49 states over 29 years).

Data sources: Avraham (2011a) for data on tort reforms (only restrictive reforms). For data on independent variables, see main text, Section 5 and Appendix.

\subsection{Legislative partisan effect on the hazard of tort reform enactment}

In order to achieve a better understanding of the partisan channel in the tort reform process, we apply the identification strategy outlined above to the state's lower houses.

Table 3 presents the findings for a partisan effect on the hazard of medical malpractice tort reform enactment (for all estimations we use the CM approach). They are based on different specifications of model (7) and estimated globally based on the whole sample. The focus is thus on $e^{\tau}$, i.e., the estimated jump at 
the threshold of 50 percent of the seats 22

Table 3: Global regression results: legislative partisan effect

\begin{tabular}{lllll}
\hline & $(1)$ & $(2)$ & $(3)$ & $(4)$ \\
\hline$e^{\tau}$ & 1.923 & $2.004^{*}$ & $2.132^{*}$ & $2.355^{* *}$ \\
Z-value & 1.617 & 1.676 & 1.903 & 2.286 \\
\hline$g(X)$ & linear & linear & quadratic & quadratic \\
Controls & No & Yes & No & Yes \\
\hline No. of observations & 1421 & 1421 & 1421 & 1421 \\
No. of events & 92 & 92 & 92 & 92 \\
Wald test & $6.68(\mathrm{p} 0.035)$ & $38.38(\mathrm{p} 0)$ & $7.43(\mathrm{p} 0.059)$ & $42.59(\mathrm{p} 0)$ \\
Likelihood ratio test & $9.173(\mathrm{p} 0.01)$ & $21.026(\mathrm{p} 0.021)$ & $10.165(\mathrm{p} 0.017)$ & $23.824(\mathrm{p} 0.013)$ \\
\hline
\end{tabular}

Notes: Cox-like proportional hazards models with repeated events. All specifications are based on a conditional model. Standard errors are clustered at the state level. Statistical significance: $* 0.1>\mathrm{p}>0.05, * * 0.05>\mathrm{p}>0.01$ and $* * * \mathrm{p}<0.01$. No. of observations reflects total state-year observations at risk (49 states over 29 years).

Data sources: Avraham (2011a) for data on tort reforms (only restrictive reforms). For data on independent variables, see main text in Section 5.

The results indicate a substantial discontinuity in the hazard of reform enactment at the threshold of a Republican majority in the lower house. The exponentiated estimated coefficient $\tau$ indicates an around twice as high instantaneous risk of tort reform enactment in states with a Republican majority compared to states with a Democratic majority. The point estimates are statistically significant for three out of four specifications. This finding can be interpreted as evidence of a rather strong partisan effect. Note that the inclusion of control variables hardly affects the size of the point estimates but does, as expected, increase the efficiency of the estimator. Following Bor et al. (2014), we illustrate the estimated discontinuity based on predicted hazards for different values of the assignment variable (here: the share of Republicans in the lower houses). Figure 5 depicts fitted values from the quadratic specification (3) in Table 3 .

\footnotetext{
${ }^{22}$ The coefficients of the other independent variables are not reported in the table. However, Table A5 in the Appendix presents all coefficient estimates, including the control variables.
} 
Figure 5: Republican majority margin and tort reform hazard rate

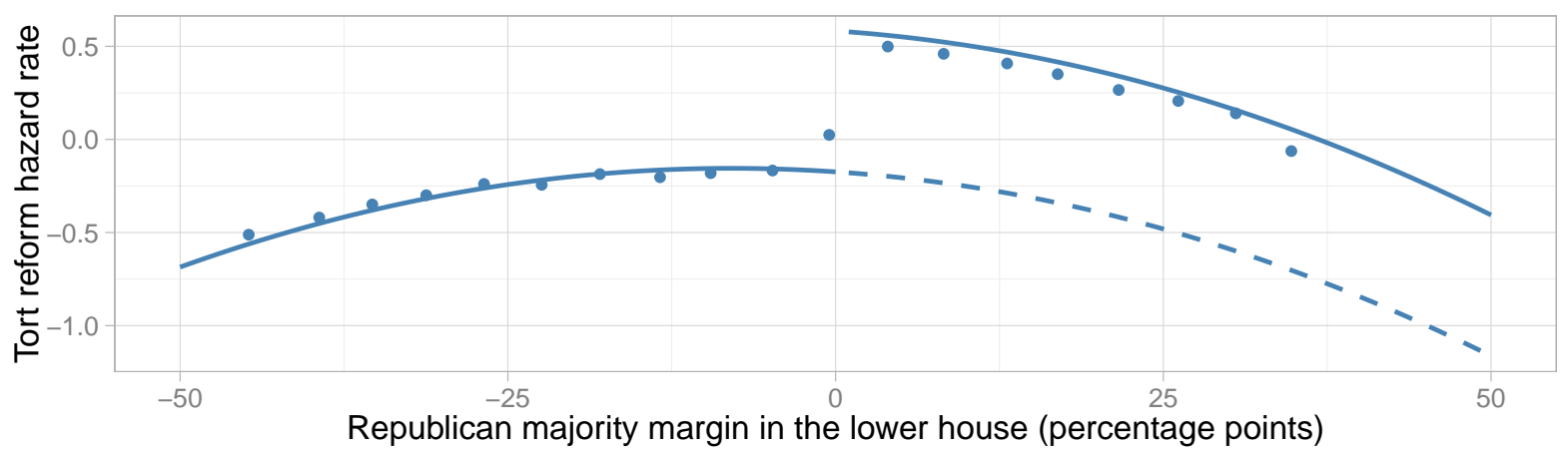

Notes: Predicted hazards from specification (3) in Table 3 are displayed as solid lines. The dashed line shows extrapolated predictions based on the estimated model below the threshold $(\tau \times D=0)$. The dots are hazards predicted for Republican majority margin count bins of 5 percentage points width.

In order to get closer to a causal interpretation of the estimated partisan effect $e^{\tau}$, we re-estimate specification (4) in Table 3 for different samples of states that were generally contested over a certain period of time. In particular, we include only those states in the sub-sample in which from the beginning of the observation period until year $y$ the majority margin of either party was constantly below 15 percentage points. The idea is thus to estimate the effect of a Republican majority in the lower house for states where in some years the Republicans had a narrow majority and in others the Democrats just won the elections by a narrow margin. The selection of the sub-samples thus has to trade off a higher number of states against a longer time-frame for the analysis. By varying $y$ over the range of 1988 to 2008, we make sure that we do not over-interpret one specific result stemming from one state/time-frame combination. Figure 6 presents the resulting exponentiated point estimates for the partisan effect (with respective $90 \%$ confidence intervals) ordered according to the last year $y$ of the respective sample's risk set.

The results indicate that for those states in which the share of Republicans was just around the majority threshold for the longest period of time, there is a clear positive discontinuity in the hazard of reform enactment. The measured partisan effects are similar in magnitude to the estimated global effect presented in Table 3. The estimates indicate that for states with electorates of comparable political ideologies, a narrow Republican majority in the lower house is associated with a hazard of tort reform enactment around two to three times as high as with a narrow Democratic majority. Note that for these estimates we exploit substantial cross-sectional as well as longitudinal variation in the data. In the case of $y=2008$, for example, in 8 of 12 states with narrow election results, majorities in the lower house switched between Democrats and Republicans during the observation period. In total, there are 34 switches in party majority in that specific 
Figure 6: Estimated partisan effect for generally contested states

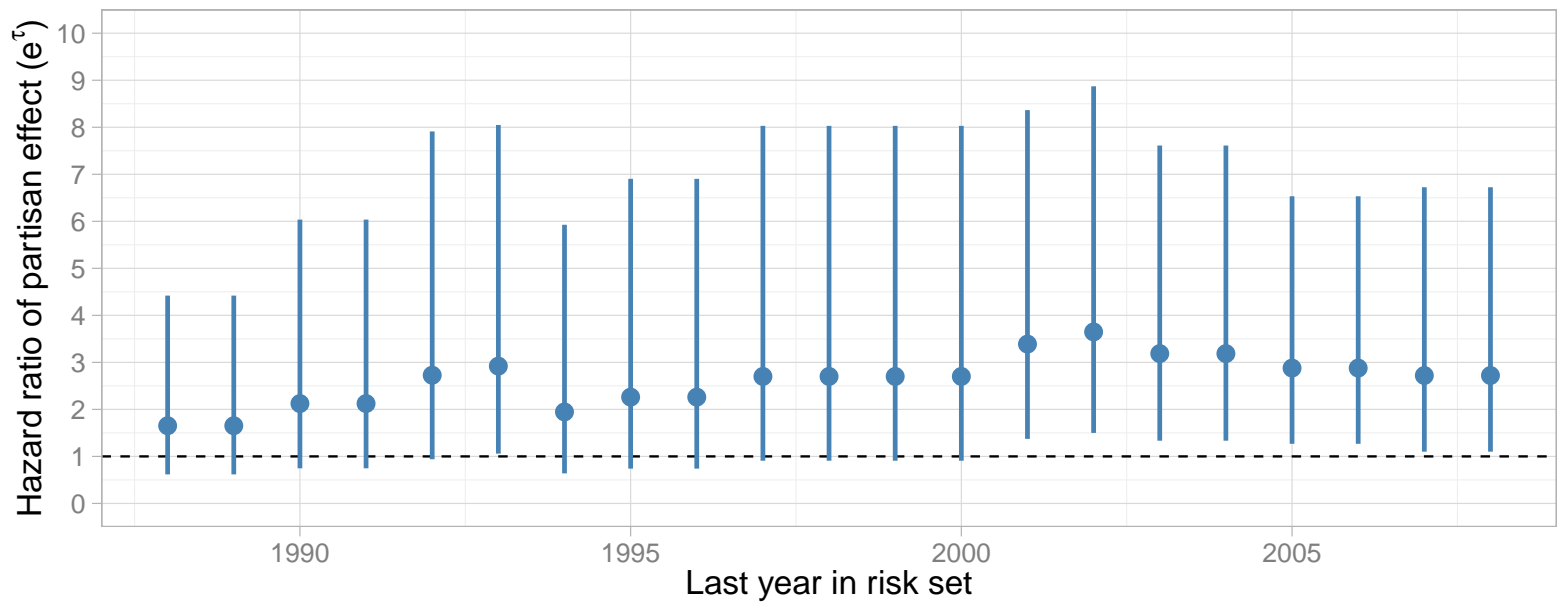

Notes: Estimated hazard ratios and $10 \%$ confidence intervals based on specification (4) in Table 3 for different time-frames and states in which the Republicans' absolute winning margin never exceeded 15 percentage points.

Data sources: Avraham (2011a) for data on tort reforms (only restrictive reforms). For data on independent variables, see main text in Section 5 and Appendix.

sub-sample.

\subsection{Executive partisan effect on the hazard of tort reform enactment}

Table 4 presents the findings for the partisan effect of a Republican governor on the hazard of tort reform enactment. It is estimated globally and based on the whole sample.

The results indicate a statistically significant jump in the hazard rate at the threshold. The inclusion of controls only slightly affects the size of the point estimate but - as in the previous analysis - reduces the size of the standard errors. As the data on gubernatorial elections do not allow a restriction of the sample to observations more closely around the threshold over a long time period, the evidence presented has to be interpreted with caution. Note, though, that in 39 out of 40 states there was at least one switch in the party holding the governorship over the observation period. 
Table 4: Global regression results: executive partisan effect

\begin{tabular}{lllll}
\hline & $(1)$ & $(2)$ & $(3)$ & $(4)$ \\
\hline$e^{\tau}$ & $1.827^{*}$ & $1.913^{* *}$ & 1.775 & $1.894^{*}$ \\
Z-value & 1.675 & 2.002 & 1.551 & 1.924 \\
\hline No. of observations & 1160 & 1160 & 1160 & 1160 \\
No. of events & 76 & 76 & 76 & 76 \\
\hline Wald test & $6.82(\mathrm{p} \mathrm{0.033)}$ & $33.98(\mathrm{p} \mathrm{0})$ & $10.12(\mathrm{p} 0.018)$ & $36.11(\mathrm{p} \mathrm{0})$ \\
Likelihood ratio test & $5.132(\mathrm{p} 0.077)$ & $25.171(\mathrm{p} \mathrm{0.005)}$ & $6.369(\mathrm{p} 0.095)$ & $25.356(\mathrm{p} \mathrm{0.008)}$ \\
$g(X)$ & linear & linear & quadratic & quadratic \\
Controls & No & Yes & No & Yes \\
\hline
\end{tabular}

Notes: Cox-like proportional hazards models with repeated events. All specifications are based on a conditional model. Standard errors are clustered at the state level. Statistical significance: $* 0.1>\mathrm{p}>0.05,{ }^{* *} 0.05>\mathrm{p}>0.01$ and ${ }^{* * *} \mathrm{p}<0.01$. No. of observations reflects total state-year observations at risk (49 states over 29 years).

Data sources: Avraham (2011a) for data on tort reforms (only restrictive reforms). For data on independent variables, see main text in Section 5 and Appendix.

\section{Concluding remarks}

U.S. tort reform is not only a controversial issue in terms of substantive law, but also in terms of understanding its drivers in the political process. There are many reports that emphasize the predominant role that special interest politics plays in shaping the reform process rather than a process of trial and error towards a tort law that is most beneficial for citizens. In order to better understand the reform process, we formulated some general hypotheses on the main forces behind tort reforms and studied them with regard to medical malpractice tort law at the state level for the United States. In so doing, we have to address the challenge that it is difficult to separate the different forces empirically, in particular, if constituency preferences as well as the position of special interest groups are potentially correlated with relative party strength. In order to identify the strength of special interests and ideology tied to the two main parties, we focus on a specific partisan effect. If relative party strength in politics primarily reflects underlying voter preferences, reform enactments are expected to be a continuous function of party representation. However, if there are special interests that gain and lose influence when one or the other party has the majority in the legislature, the likelihood of reforms is expected to change systematically at this threshold. A similar discontinuity in reform enactment is expected to hold if the governorship changes hands from one party to the other.

Based on Cox proportional hazards estimations, we find evidence that relative party strength in state legislatures and governors' party affiliations are related to the enactment of tort reforms. The stronger Republican representation is in politics, the more likely it is that a reform will be passed at any point in time. 
For the estimation of a specific partisan effect, we apply the idea behind the regression discontinuity design and augment the Cox proportional hazards model accordingly. We find a substantial partisan effect in the case of the lower house, with around a 100 percent higher hazard of reform enactment with a Republican rather than a Democratic majority. This holds if we restrict the sample to states with generally contested elections. A partisan effect of similar magnitude is estimated for a Republican governorship. The respective estimate has to rely on the full sample. As a supplementary finding, we observe that the hazard of reform is systematically lower when there is a larger fraction of female legislators. This is consistent with genderspecific consequences of tort reforms being less beneficial or even harmful to women. No evidence is found for a functional explanation of the reform process: there is no higher hazard of reform in states where physicians faced a higher liability risk in the early 1980s.

The insights on the reform process have implications for the evaluation of the consequences of tort reforms. Reform enactments should no longer be considered discrete random events, but should, instead, be expected to entail further policy changes that are related to the political orientation of a state's governor and legislators. In other words, the validity of the common trend assumption in difference-in-differences analyses needs to be studied carefully. We are convinced that further joint analyses of the tort reform process and its consequences will help to provide a better understanding of its costs and benefits. 


\section{Acknowledgements}

We are grateful to two anonymous referees, Thomas Braendle, Jerg Gutmann, Thorsten Henne, Margaret Kyle, Reto Odermatt, Catherine Sharkey, Joanna Shepherd, Thomas Stratmann, and conference participants at the EPCS Meeting 2014, as well as seminar participants at ETH Zurich, the University of Basel, and the University of Zurich for helpful remarks. Special thanks go to Mark Showalter and Eric Helland for providing data on liability risk; and to Beth Rosenson for providing data on the occupational composition of U.S. state legislatures. We also thank Laura Sochaczewski for excellent research assistance. Ulrich Matter acknowledges financial support from the WWZ Forum. 


\section{References}

Albouy, D. (2013). Partisan Representation in Congress and the Geographic Distribution of Federal Funds. The Review of Economics and Statistics, 95(1):127-141.

Andersen, P. K. and Gill, R. D. (1982). Cox's Regression Model for Counting Processes: A Large Sample Study. Annals of Statistics, 10(4):1100-1120.

Avraham, R. (2007). An Empirical Study of the Impact of Tort Reforms on Medical Malpractice Settlement Payments. Journal of Legal Studies, 36(S2):183-229.

Avraham, R. (2011a). Database of State Tort Law Reforms (3rd), 1980-2008 [online, last checked 11/09/2015]. Available from: http://dx.doi.org/10.3886/ICPSR30409.v1.

Avraham, R. (2011b). Database of State Tort Law Reforms (DSTLR 4th). Law and Econ Research Paper 184, University of Texas School of Law.

Bor, J., Moscoe, E., Mutevedzi, P., Newell, M.-L., and Bärnighausen, T. (2014). Regression Discontinuity Designs in Epidemiology: Causal Inference Without Randomized Trials. Epidemiology, 25(5):729-737.

Box-Steffensmeier, J. M. and Zorn, C. (2002). Duration Models for Repeated Events. Journal of Politics, 64(4):1069-1094.

Calabresi, G. (1970). The Costs of Accidents: A Legal and Economic Analysis. Yale University Press, New Haven, CT.

Campbell, T. J., Kessler, D. P., and Shepherd, G. B. (1995). The Causes and Effects of Liability Reform: Some Empirical Evidence. Working Paper No. 4989, National Bureau of Economic Research, Cambridge, MA.

Carvell, D., Currie, J., and MacLeod, W. B. (2012). Accidental Death and the Rule of Joint and Several Liability. RAND Journal of Economics, 43(1):51-77.

Coase, R. H. (1960). The Problem of Social Cost. Journal of Law and Economics, 3:1-44.

Cox, D. R. (1972). Regression Models and Life-Tables. Journal of the Royal Statistical Society. Series B (Methodological), 34(2):187-220.

Currie, J. and MacLeod, W. B. (2008). First Do No Harm? Tort Reform and Birth Outcomes. Quarterly Journal of Economics, 123(2):795-830. 
Donohue, J. J. and Ho, D. E. (2007). The Impact of Damage Caps on Malpractice Claims: Randomization Inference with Difference-in-Differences. Journal of Empirical Legal Studies, 4(1):69-102.

Epstein, R. A. (1988). The Political Economy of Product Liability Reform. American Economic Review, $78(2): 311-315$.

Ferreira, F. and Gyourko, J. (2009). Do Political Parties Matter? Evidence from U.S. Cities. The Quarterly Journal of Economics, 124(1):399-422.

Frakes, M. and Jena, A. B. (2014). Does Medical Malpractice Law Improve Healrh Care Quality. NBER Working Paper 19841, National Bureau of Economic Research.

Gelman, A. and Imbens, G. (2014). Why High-order Polynomials Should not be Used in Regression Discontinuity Designs. Working Paper 20405, National Bureau of Economic Research.

Helland, E. and Showalter, M. H. (2009). The Impact of Liability on the Physician Labor Market. Journal of Law and Economics, 52(4):635-663.

Inter-University Consortium for Political and Social Research (1984). Candidate and Constituency Statistics of Elections in the United States, 1788-1990 [online, last checked 11/09/2015]. Available from: http: //doi.org/10.3886/ICPSR07757.v5

Kessler, D. and McClellan, M. (1996). Do Doctors Practice Defensive Medicine? Quarterly Journal of Economics, 111(2):353-390.

Kleinbaum, D. and Klein, M. (2005). Survival Analysis: A Self-Learning Text. Statistics for Biology and Health. Springer, New York, NY, third edition.

Klick, J. and Sharkey, C. M. (2009). What Drives the Passage of Damage Caps? In Empirical Studies of Judicial Systems Around the Globe. Institutum Jurisprudentiae, Academia Sinica.

Klick, J. and Stratmann, T. (2007). Medical Malpractice Reform and Physicians in High-Risk Specialties. Journal of Legal Studies, 36(2):121-142.

Lee, D. S. (2001). The Electoral Advantage to Incumbency and Voters' Valuation of Politicians' Experience: A Regression Discontinuity Analysis of Elections to the U.S. House. Working Paper 8441, National Bureau of Economic Research.

Lee, D. S. and Lemieux, T. (2010). Regression Discontinuity Designs in Economics. Journal of Economic Literature, 48(2):281-355. 
Lee, D. S., Moretti, E., and Butler, M. J. (2004). Do Voters Affect or Elect Policies? Evidence from the U. S. House. The Quarterly Journal of Economics, 119(3):807-859.

Leip, D. (2013). United States Gubernatorial Election Results [online, last checked 11/5/2015]. Available from: http://uselectionatlas.org/RESULTS/index.html.

Lindquist, S. A. (2007). Updated State Politics Data with Judiciary Politics Data [online, last checked 07/01/2013]. Available from: http://academic.udayton.edu/sppq-TPR/DATASETS/statedata.xls.

Matter, U. and Stutzer, A. (2015). The Role of Lawyer-Legislators in Shaping the Law: Evidence from Voting on Tort Reforms. Journal of Law and Economics, 58(2):357-384.

McCrary, J. (2008). Manipulation of the Running Variable in the Regression Discontinuity Design: A Density Test. Journal of Econometrics, 142(2):698 - 714. The regression discontinuity design: Theory and applications.

Miceli, T. J. and Stone, M. P. (2013). The Determinants of State-Level Caps on Punitive Damages: Theory and Evidence. Contemporary Economic Policy, 31(1):110-125.

Olson, M. (1965). The Logic of Collective Action: Public Goods and the Theory of Groups. Harvard University Press, Cambridge, MA.

Olson, W. K. (2003). The Rule of Lawyers: How the New Litigation Elite Threatens America's Rule of Law. St. Martin's Press, New York, NY.

Paik, M., Black, B., and Hyman, D. (2013). The Receding Tide of Medical Malpractice Litigation: Part 2-Effect of Damage Caps. Journal of Empirical Legal Studies, 10(4):639-669.

Pettersson-Lidbom, P. (2008). Do Parties Matter for Economic Outcomes? A Regression-Discontinuity Approach. Journal of the European Economic Association, 6(5):1037-1056.

Pintoff, R. (2004). The Impact of Incarceration on Juvenile Crime: A Regression Discontinuity Approach. Technical report, Working Paper.

Poole, K. T. and Rosenthal, H. (1985). A Spatial Model for Legislative Roll Call Analysis. American Journal of Political Science, 29(2):357-384.

Prentice, R. L., Williams, B. J., and Peterson, A. V. (1981). On the Regression Analysis of Multivariate Failure Time Data. Biometrika, 68(2):373-379. 
Rosenson, B. A. (2006). The Impact of Ethics Laws on Legislative Recruitment and the Occupational Composition of State Legislatures. Political Research Quarterly, 59(4):619-627.

Rubin, P. H. (2005). Public Choice and Tort Reform. Public Choice, 124(1/2):223-236.

Rubin, P. H. and Bailey, M. J. (1994). The Role of Lawyers in Changing the Law. Journal of Legal Studies, $23(2): 807-831$.

Rubin, P. H., Curran, C., and Curran, J. F. (2001). Litigation Versus Legislation: Forum Shopping by Rent Seekers. Public Choice, 107(3/4):295-310.

Rubin, P. H. and Shepherd, J. M. (2007). Tort Reform and Accidental Deaths. Journal of Law and Economics, $50(2): 221-238$.

Rubin, P. H. and Shepherd, J. M. (2008). The Demographics of Tort Reform. Review of Law and Economics, $4(2): 591-620$.

Shavell, S. (1987). Economic Analysis of Accident Law. Harvard University Press, Cambridge, MA.

Shepherd, J. M. (2008). Tort Reforms' Winners and Losers: The Competing Effects of Care and Activity Levels. UCLA Law Review, 55(4):914-919.

Sloan, F. A. and Shadle, J. H. (2009). Is There Empirical Evidence for "Defensive Medicine"? A Reassessment. Journal of Health Economics, 28(2):481 - 491.

Sugarman, S. D. (2002). United States Tort Reform Wars. University of New South Wales Law Journal, $25(3): 849-853$.

Sugarman, S. D. (2006). Ideological Flip-Flop: American Liberals Are Now the Primary Supporters of Tort Law. In Tiberg, H. and Clarke, M., editors, Essays on Tort, Insurance, Law and Society in Honour of Bill W. Dufwa, pages 1105-1102. Jure Forlag AB, Stockholm.

Therneau, T. and Grambsch, P. (2000). Modeling Survival Data: Extending the Cox Model. Statistics for Biology and Health. Springer, New York, NY.

Therneau, T. M. and Hamilton, S. A. (1997). rhDNase as an Example of Recurrent Event Analysis. Statistics in Medicine, 16(18):2029-2047.

Towers Watson (2012). U.S. Tort Costs Trends 2011 Update. Towers Watson, New York, NY. 
U.S. Council of Economic Advisers (2004). Economic Report of the President. U.S. Council of Economic Advisers, Washington, DC.

Viscusi, W. K. and Born, P. H. (2005). Damages Caps, Insurability, and the Performance of Medical Malpractice Insurance. Journal of Risk and Insurance, 72(1):23-43.

Voteview.com (2012). DW-Nominate Scores [online, last checked 11/09/2015]. Available from: http://www. voteview.com/dwnominate.asp

Zywicki, T. J. (2000). Public Choice and Tort Reform. George Mason Law and Economics Research Paper 00-36, George Mason University School of Law. 


\section{Appendix}

\section{A.1 Monte Carlo study}

We illustrate the intuition behind our empirical approach with a small Monte Carlo study.

\section{Draws of simulated data}

In our simulations, the data generating process has at its core a quadratic function of an assignment variable $X$ which is discontinuous at $X>0$. For the systematic component of the data generating process, we first draw the vector of the assignment variable from a uniform distribution, $X \sim U(-0.5,0.5)$. We then generate vector $\lambda$ as $\lambda=e^{\left(\beta_{1} X+\beta_{2} X^{2}+\tau 1[X>0]\right)}$.

For 2,000 repetitions, we then use the systematic component $\lambda$ to produce the dependent variable $Y$ (survival times) from the exponential distribution.

\section{Results}

We set the real parameter values as $\beta_{1}=0.3, \beta_{2}=-0.5$, and $\tau=0.2$. In each repetition, we fit a Cox model to the respective simulated sample and record the point estimate of $\tau$. We illustrate the performance of the Cox estimator of $\tau$ given the real parameter values and a sample size comparable to our real world data set $(N=1500)$. Figure A1a displays the distribution of the point estimates for $\tau$ alongside the mean of all repetitions as well as the real parameter value. On average, the point estimator for $\tau$ is numerically very close to the real value of 0.2 . For each estimated Cox model we then predict the hazard rate based on the estimated coefficients and the random sample of explanatory variables. Figure A1b shows bins of the predicted hazard rates for assignment variable values below and above the threshold of 0 . The figure intuitively illustrates how we can interpret the idea of an RDD in the context of proportional hazards modelling. The discontinuity incorporated in the underlying data generating process can consistently be retrieved and reproduced by means of a Cox proportional hazards model. 
Figure A1: Illustration of simulation results

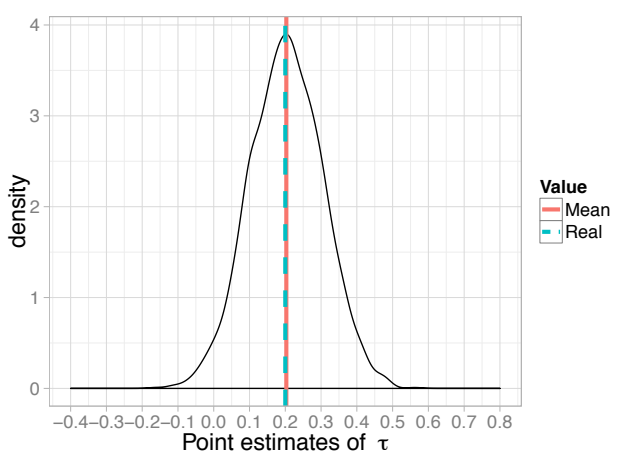

(a) Distribution of estimated coefficients

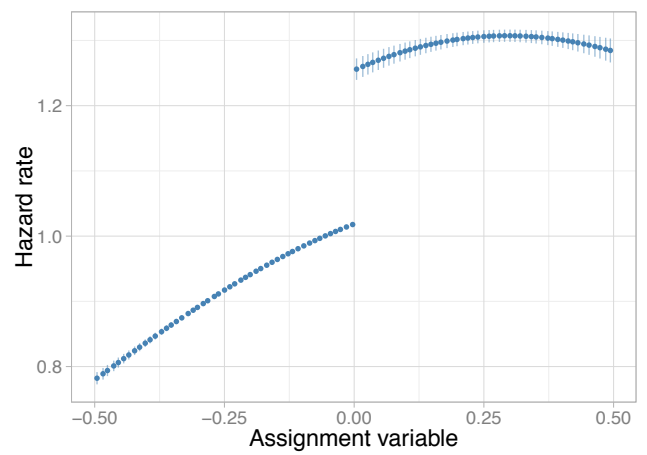

(b) Bins of predicted hazard rates

\section{A.2 Reforms in medical malpractice tort law by state}

Table A1: Reforms and states included in individual reform analyses

\begin{tabular}{|c|c|c|c|c|c|}
\hline State & $\begin{array}{l}\text { Punitive } \\
\text { damages } \\
\text { caps }\end{array}$ & $\begin{array}{l}\text { Punitive evi- } \\
\text { dence }\end{array}$ & $\begin{array}{l}\text { Non- } \\
\text { economic } \\
\text { damages } \\
\text { caps }\end{array}$ & $\begin{array}{l}\text { Collateral- } \\
\text { source rule }\end{array}$ & $\begin{array}{l}\text { Joint-and- } \\
\text { several } \\
\text { liability }\end{array}$ \\
\hline Alaska & 1997 & 1986 & 2005 & & 1986 \\
\hline Alabama & 1987 & 1987 & 1987 & 1987 & \\
\hline Arkansas & & 2003 & & & 2003 \\
\hline Arizona & & & & & 1987 \\
\hline California & & 1988 & & & 1986 \\
\hline Colorado & 1986 & & 1986 & 1986 & 1986 \\
\hline Connecticut & & & & 1985 & 1986 \\
\hline Delaware & & & & & \\
\hline Florida & & 1999 & 2003 & & 1986 \\
\hline Georgia & 1987 & 1987 & 2005 & & 1987 \\
\hline Hawaii & & & 1987 & 1987 & 1987 \\
\hline Iowa & & 1986 & & & 1984 \\
\hline Idaho & 2003 & 1987 & 1987 & 1990 & 1987 \\
\hline Illinois & 1985 & & & & \\
\hline Indiana & 1995 & 1984 & & 1986 & \\
\hline Kansas & 1987 & 1987 & 1986 & & \\
\hline Kentucky & & 1988 & & 1988 & 1988 \\
\hline Louisiana & & & & & 1980 \\
\hline Massachusetts & & & & 1986 & \\
\hline Maryland & & & 1986 & & \\
\hline Maine & & & & 1990 & \\
\hline Michigan & & & & 1986 & 1986 \\
\hline Minnesota & & & 1986 & 1985 & 1988 \\
\hline Missouri & 2005 & 1986 & 1986 & & 1986 \\
\hline Mississippi & & 1993 & 2003 & & 1989 \\
\hline Montana & & 1985 & 1995 & 1987 & 1987 \\
\hline
\end{tabular}


Table A1 - continued from previous page

\begin{tabular}{|c|c|c|c|c|c|}
\hline State & $\begin{array}{l}\text { Punitive } \\
\text { damages } \\
\text { caps }\end{array}$ & $\begin{array}{l}\text { Punitive evi- } \\
\text { dence }\end{array}$ & $\begin{array}{l}\text { Non- } \\
\text { economic } \\
\text { damages } \\
\text { caps }\end{array}$ & $\begin{array}{l}\text { Collateral- } \\
\text { source rule }\end{array}$ & $\begin{array}{ll}\text { Joint } & \text { and } \\
\text { several } & \\
\text { liability } & \end{array}$ \\
\hline North Carolina & 1996 & 1996 & & & \\
\hline North Dakota & 1993 & 1987 & 1995 & 1987 & 1987 \\
\hline New Hampshire & 1986 & & & & 1990 \\
\hline New Jersey & 1995 & 1995 & & 1987 & 1987 \\
\hline New Mexico & & & & & 1987 \\
\hline Nevada & 1989 & 1989 & 2002 & & 2002 \\
\hline New York & & & & 1984 & 1986 \\
\hline Ohio & 2005 & 1988 & & & 2003 \\
\hline Oklahoma & 1995 & 1987 & 2003 & 2003 & 2004 \\
\hline Oregon & 1987 & 1987 & 1987 & 1987 & \\
\hline Pennsylvania & 1997 & & & & 2002 \\
\hline Rhode Island & & & & & \\
\hline South Carolina & & 1988 & 2005 & & 2005 \\
\hline South Dakota & & & & & \\
\hline Tennessee & & & & & \\
\hline Texas & & 1987 & 2003 & & 1985 \\
\hline Utah & & 1989 & 1987 & 1986 & 1986 \\
\hline Virginia & 1988 & & & & \\
\hline Vermont & & & & & \\
\hline Washington & & & & & 1986 \\
\hline Wisconsin & 1985 & 1995 & 1995 & 1995 & 1994 \\
\hline West Virginia & & & 2003 & 2003 & 1986 \\
\hline Wyoming & & & & & 1986 \\
\hline No. of reforms & 20 & 25 & 22 & 20 & 34 \\
\hline
\end{tabular}

Note: The indicated years refer to the first enactment (after 1979) of the respective reform in the respective state.

Data source: Avraham (2011a). 


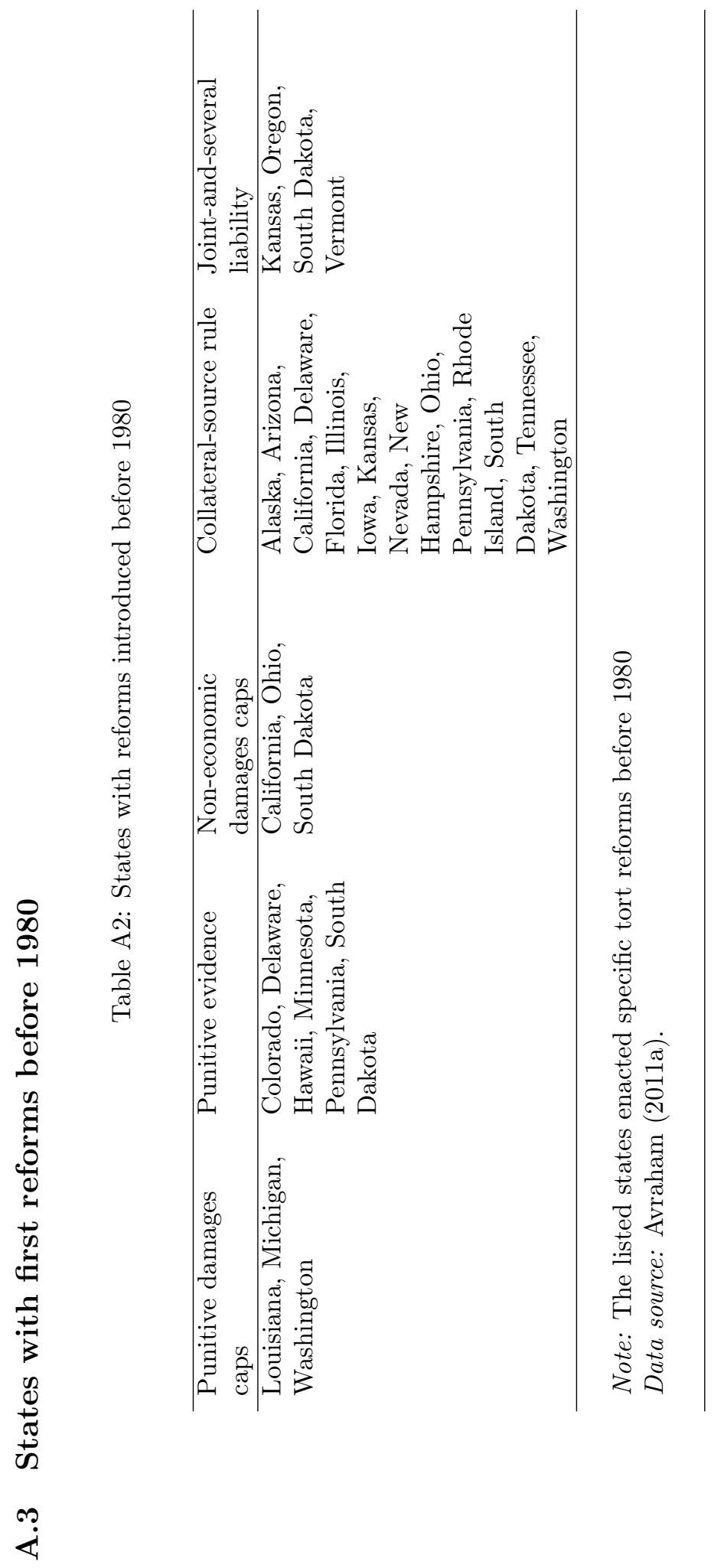




\section{A.4 Data appendix: control variables}

Liability index: To control for the reform pressure in a state in the early 1980s we use the liability risk measure (i.e., an estimation of the expected liability costs) proposed by Helland and Showalter (2009). The liability risk measure is based on detailed liability award data in Florida, in combination with aggregate award data from all other states and is estimated by state and physicians' field of specialization in 1983 and 1988. In our specifications we include the average expected liability costs (averaged over specialities, in USD 100) by state in the year 1983.

Liberal political orientation: The mean of the DW-Nominate scores (first dimension) of the members of Congress is used as a proxy for the political preferences of a state's electorate. The scores are based on member of Congress' roll call records. We code the scores such that higher ratings reflect a more liberal attitude (the scores thus range from -1 to +1 , whereby +1 reflects a most liberal political orientation) ${ }^{23}$ The data for this variable come from Voteview.com (2012).

Health sector share of gross state product (GSP) and legal sector share of GSP (in \%): We use the percentage of the health (legal) sectors' contribution to the state's gross domestic product as a proxy for the financial and political power of the health (legal) lobby in a state. The data comes from the U.S. Department of Commerce, Bureau of Economic Analysis.

Real GSP per capita (in USD 1,000): Data on this variable come from the U.S. Department of Commerce, Bureau of Economic Analysis.

Percentage of women in the legislature: Information on the percentage of women legislators is available for all states and comes from the Center for American Women in Politics of the Eagleton Institute of Politics, State University of New Jersey.

Percentage of attorneys in the legislature: Data on the professional composition of all U.S. state legislatures is only available for the years 1986, 1993, 1995, and 2007. The data is based on surveys undertaken by the National Conference of State Legislators ${ }^{24}$ Values for unavailable years have been estimated in a first step by keeping the percentage of attorneys in the legislature over each legislative period in each state constant for which at least one year was available. The remaining missing values have been estimated using linear interpolation.

\footnotetext{
${ }^{23}$ See Poole and Rosenthal (1985) for a detailed introduction to DW-Nominate scores.

${ }^{24}$ Data for the initial waves comes from Rosenson (2006).
} 


\section{A.5 Excluded reforms}

Table A3: Common law reforms (excluded)

\begin{tabular}{llll}
\hline State & Reform & Citation & Effective date \\
\hline Arizona & Punitive damages (evidence) & $\begin{array}{l}\text { Linthicum v. Nationwide Life } \\
\text { Ins. Co., 723 P.2d 675, 680 }\end{array}$ & July 23, 1986 \\
& & (Ariz. 1986) \\
Maine & Punitive damages (evidence) & $\begin{array}{l}\text { Tuttel v. Raymond , 494 A.2d } \\
\text { 1353 (Me. 1985) }\end{array}$ & June 21, 1985 \\
Maryland & Punitive damages (evidence) & $\begin{array}{l}\text { Owens-Illinois v. Zenobia, 601 } \\
\text { A.2d 633 (Md. 1992) }\end{array}$ & February 14, 1992 \\
Tennessee & Joint and several liability & $\begin{array}{l}\text { McIntyre v. Balentine, 833 } \\
\text { S.W.2d 52 }\end{array}$ & May 4, 1992 \\
& & $\begin{array}{l}\text { Hodges v. S.C. Toof \& Co., 833 } \\
\text { Tennessee }\end{array}$ & Punitive damages (evidence) 20, 1992 \\
& & S.W.2d 896 & \\
\hline
\end{tabular}

Notes: Reforms that have been identified as enacted by a judicial decision and have consequently been excluded from the dataset used in our analyses. All information on the reforms mentioned in this table is cited as written in Avraham (2011b). 


\section{A.6 Sample selection}

Figure A2: Aggregate distributions of Republican winning margins

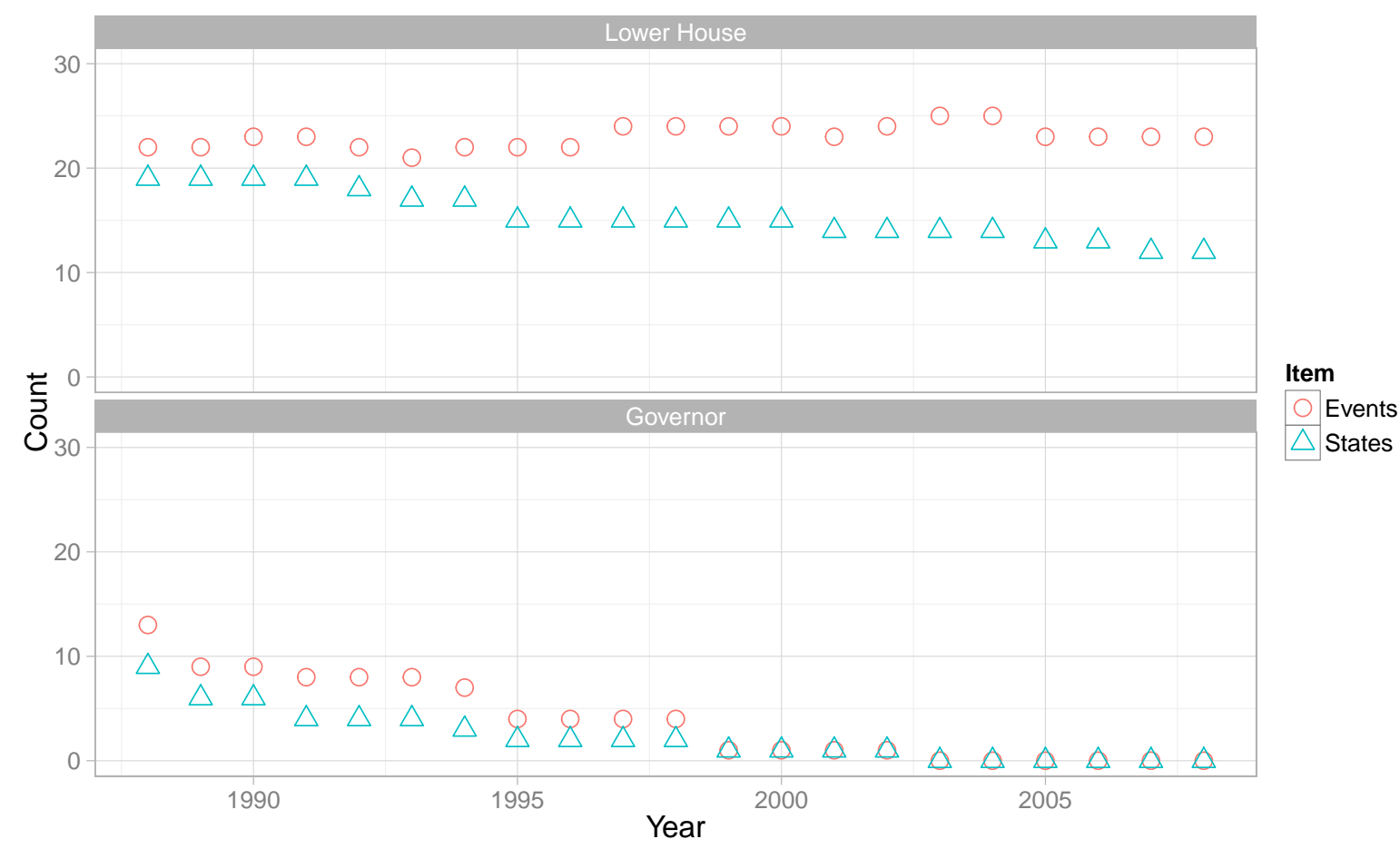

Notes: The panel shows the counts of events and states in subsamples of states in which the (absolute) Republican majority never exceeds 15 percentage points for varying time-frames (different last year of the risk set). Data sources: See Section 5 in the main text. 
Table A4: States in selected subsamples with contested elections

\begin{tabular}{|c|c|c|}
\hline Last year & Lower House & Governor \\
\hline 1988 & $\begin{array}{l}\text { AK, CA, DE, IA, IL, IN, KS, ME, MI, MN, } \\
\text { MT, NJ, OH, OR, PA, TN, VT, WA, WI }\end{array}$ & KS, MO, ND, NM, PA, TX, VA, WA, WI \\
\hline 1989 & $\begin{array}{l}\text { AK, CA, DE, IA, IL, IN, KS, ME, MI, MN, } \\
\text { MT, NJ, OH, OR, PA, TN, VT, WA, WI }\end{array}$ & $\mathrm{KS}, \mathrm{NM}, \mathrm{PA}, \mathrm{TX}, \mathrm{VA}, \mathrm{WI}$ \\
\hline 1990 & $\begin{array}{l}\text { AK, CA, DE, IA, IL, IN, KS, ME, MI, MN, } \\
\text { MT, NJ, OH, OR, PA, TN, VT, WA, WI }\end{array}$ & $\mathrm{KS}, \mathrm{NM}, \mathrm{PA}, \mathrm{TX}, \mathrm{VA}, \mathrm{WI}$ \\
\hline 1991 & $\begin{array}{l}\text { AK, CA, DE, IA, IL, IN, KS, ME, MI, MN, } \\
\text { MT, NJ, OH, OR, PA, TN, VT, WA, WI }\end{array}$ & $\mathrm{KS}, \mathrm{NM}, \mathrm{TX}, \mathrm{VA}$ \\
\hline 1992 & $\begin{array}{l}\text { AK, CA, DE, IA, IL, IN, KS, ME, MI, MN, } \\
\text { MT, OH, OR, PA, TN, VT, WA, WI }\end{array}$ & $\mathrm{KS}, \mathrm{NM}, \mathrm{TX}, \mathrm{VA}$ \\
\hline 1993 & $\begin{array}{l}\text { AK, CA, DE, IA, IL, IN, KS, ME, MI, MN, } \\
\text { MT, OH, OR, PA, TN, VT, WI }\end{array}$ & KS, NM, TX, VA \\
\hline 1994 & $\begin{array}{l}\text { AK, CA, DE, IA, IL, IN, KS, ME, MI, MN, } \\
\text { MT, OH, OR, PA, TN, VT, WI }\end{array}$ & KS, NM, TX \\
\hline 1995 & $\begin{array}{l}\text { AK, CA, IA, IL, IN, KS, ME, MI, MN, OH, } \\
\text { OR, PA, TN, VT, WI }\end{array}$ & NM, TX \\
\hline 1996 & $\begin{array}{l}\text { AK, CA, IA, IL, IN, KS, ME, MI, MN, OH, } \\
\text { OR, PA, TN, VT, WI }\end{array}$ & NM, TX \\
\hline 1997 & $\begin{array}{l}\text { AK, CA, IA, IL, IN, KS, ME, MI, MN, OH, } \\
\text { OR, PA, TN, VT, WI }\end{array}$ & NM, TX \\
\hline 1998 & $\begin{array}{l}\text { AK, CA, IA, IL, IN, KS, ME, MI, MN, OH, } \\
\text { OR, PA, TN, VT, WI }\end{array}$ & NM, TX \\
\hline 1999 & $\begin{array}{l}\text { AK, CA, IA, IL, IN, KS, ME, MI, MN, OH, } \\
\text { OR, PA, TN, VT, WI }\end{array}$ & NM \\
\hline 2000 & $\begin{array}{l}\text { AK, CA, IA, IL, IN, KS, ME, MI, MN, OH, } \\
\text { OR, PA, TN, VT, WI }\end{array}$ & NM \\
\hline 2001 & $\begin{array}{l}\text { CA, IA, IL, IN, KS, ME, MI, MN, OH, OR, } \\
\text { PA, TN, VT, WI }\end{array}$ & NM \\
\hline 2002 & $\begin{array}{l}\text { CA, IA, IL, IN, KS, ME, MI, MN, OH, OR, } \\
\text { PA, TN, VT, WI }\end{array}$ & NM \\
\hline 2003 & $\begin{array}{l}\text { CA, IA, IL, IN, KS, ME, MI, MN, OH, OR, } \\
\text { PA, TN, VT, WI }\end{array}$ & - \\
\hline 2004 & $\begin{array}{l}\text { CA, IA, IL, IN, KS, ME, MI, MN, OH, OR, } \\
\text { PA, TN, VT, WI }\end{array}$ & - \\
\hline 2005 & $\begin{array}{l}\text { CA, IA, IL, IN, ME, MI, MN, OH, OR, PA, } \\
\text { TN, VT, WI }\end{array}$ & - \\
\hline 2006 & $\begin{array}{l}\text { CA, IA, IL, IN, ME, MI, MN, OH, OR, PA, } \\
\text { TN, VT, WI }\end{array}$ & - \\
\hline 2007 & $\begin{array}{l}\text { CA, IA, IL, IN, ME, MI, MN, OH, OR, PA, } \\
\text { TN, WI }\end{array}$ & - \\
\hline 2008 & $\begin{array}{l}\text { CA, IA, IL, IN, ME, MI, MN, OH, OR, PA, } \\
\text { TN, WI }\end{array}$ & - \\
\hline
\end{tabular}

Notes: $\mathrm{N}=1421$. The data consist of yearly observations for 49 U.S. states (We exclude data on Nebraska from the analysis due to the lack of information on party strength in its nonpartisan legislature.) from 1980 to 2008.

Data source: See main text in Section 5 and the data Appendix. 


\section{A.7 Additional results}

Table A5: Global regression results: legislative partisan effect, all variables

\begin{tabular}{|c|c|c|c|c|}
\hline & (1) & $(2)$ & (3) & $(4)$ \\
\hline$e^{\tau}$ & $\begin{array}{l}1.923 \\
(1.617)\end{array}$ & $\begin{array}{l}2.004^{*} \\
(1.676)\end{array}$ & $\begin{array}{l}2.132 * \\
(1.903)\end{array}$ & $\begin{array}{l}2.355 \text { ** } \\
(2.286)\end{array}$ \\
\hline LH: Republican majority margin & $\begin{array}{l}1.001 \\
(0.088)\end{array}$ & $\begin{array}{l}1.005 \\
(0.415)\end{array}$ & $\begin{array}{l}0.995 \\
(-0.500)\end{array}$ & $\begin{array}{l}0.996 \\
(-0.326)\end{array}$ \\
\hline LH: Republican majority margin ${ }^{2}$ & & & $\begin{array}{l}1.000 \\
(-1.146)\end{array}$ & $\begin{array}{l}0.999 * \\
(-1.805)\end{array}$ \\
\hline Governor: Republican winning margin & & $\begin{array}{l}1.005 \\
(0.978)\end{array}$ & & $\begin{array}{l}1.005 \\
(1.085)\end{array}$ \\
\hline Liability risk (in USD 100) & & $\begin{array}{l}0.997 \\
(-0.536)\end{array}$ & & $\begin{array}{l}0.997 \\
(-0.631)\end{array}$ \\
\hline Liberal political orientation & & $\begin{array}{l}0.510 \\
(-0.660)\end{array}$ & & $\begin{array}{l}0.439 \\
(-0.775)\end{array}$ \\
\hline GSP health industry (\%) & & $\begin{array}{l}1.027 \\
(0.176)\end{array}$ & & $\begin{array}{l}0.987 \\
(-0.081)\end{array}$ \\
\hline GSP legal industry (\%) & & $\begin{array}{l}1.759 \\
(1.435)\end{array}$ & & $\begin{array}{l}1.748 \\
(1.338)\end{array}$ \\
\hline Attorneys in legislature (\%) & & $\begin{array}{l}1.005 \\
(0.243)\end{array}$ & & $\begin{array}{l}1.003 \\
(0.136)\end{array}$ \\
\hline Women in legislature (\%) & & $\begin{array}{l}0.964 * \\
(-1.833)\end{array}$ & & $\begin{array}{l}0.964 * \\
(-1.781)\end{array}$ \\
\hline Real GSP p.c. (in USD 1,000) & & $\begin{array}{l}0.972 \\
(-0.485)\end{array}$ & & $\begin{array}{l}0.957 \\
(-0.688)\end{array}$ \\
\hline No. of observations & 1421 & 1421 & 1421 & 1421 \\
\hline No. of events & 92 & 92 & 92 & 92 \\
\hline Wald test & $6.68(\mathrm{p} 0.035)$ & $38.38($ p 0$)$ & $7.43(\mathrm{p} 0.059)$ & $42.59(\mathrm{p} 0)$ \\
\hline Likelihood ratio test & $9.173(\mathrm{p} 0.01)$ & $21.026(\mathrm{p} 0.021)$ & $10.165(\mathrm{p} 0.017)$ & $23.824($ p 0.013$)$ \\
\hline
\end{tabular}

Notes: The presented estimates are exponentiated coefficients from Cox-like proportional hazards models with repeated events. All specifications are based on a conditional model. Standard errors are clustered at the state level. Statistical significance: ${ }^{*} 0.1>\mathrm{p}>0.05,{ }^{* *} 0.05>\mathrm{p}>0.01$ and ${ }^{* * *} \mathrm{p}<0.01$. No. of observations reflects total state-year observations at risk (49 states over 29 years).

Data sources: Avraham (2011a) for data on tort reforms (only restrictive reforms). For data on independent variables, see main text in Section 5 and the data Appendix. 